\title{
Light-controlled flavonoid biosynthesis in fruits
}

\author{
Laura Zoratti ${ }^{1}$, Katja Karppinen ${ }^{1}$, Ana Luengo Escobar ${ }^{2}$, Hely Häggman ${ }^{1}$ and Laura Jaakola ${ }^{3,4}$ * \\ ${ }^{1}$ Department of Biology, University of Oulu, Oulu, Finland \\ 2 Programa de Doctorado en Ciencias de Recursos Naturales, Universidad de la Frontera, Temuco, Chile \\ ${ }^{3}$ Climate laboratory Holt, Department of Arctic and Marine Biology, UiT The Arctic University of Norway, Tromsø, Norway \\ ${ }^{4}$ Norwegian Institute for Agricultural and Environmental Research, Bioforsk Nord Holt, Tromsø, Norway
}

Edited by:

Francesco Damiani, Consiglio

Nazionale Delle Ricerche, Italy

\section{Reviewed by:}

Keiko Yonekura-Sakakibara, RIKEN,

Japan

Guillermo Schmeda-Hirschmann

Universidad de Talca, Chile

*Correspondence:

Laura Jaakola, Climate laboratory

Holt, Department of Arctic and

Marine Biology, UiT The Arctic

University of Norway, Holtveien 62,

NO-9037 Tromsø, Norway

e-mail: laura.jaakola@uit.no
Light is one of the most important environmental factors affecting flavonoid biosynthesis in plants. The absolute dependency of light to the plant development has driven evolvement of sophisticated mechanisms to sense and transduce multiple aspects of the light signal. Light effects can be categorized in photoperiod (duration), intensity (quantity), direction and quality (wavelength) including UV-light. Recently, new information has been achieved on the regulation of light-controlled flavonoid biosynthesis in fruits, in which flavonoids have a major contribution on quality. This review focuses on the effects of the different light conditions on the control of flavonoid biosynthesis in fruit producing plants. An overview of the currently known mechanisms of the light-controlled flavonoid accumulation is provided. R2R3 MYB transcription factors are known to regulate by differential expression the biosynthesis of distinct flavonoids in response to specific light wavelengths. Despite recent advances, many gaps remain to be understood in the mechanisms of the transduction pathway of light-controlled flavonoid biosynthesis. A better knowledge on these regulatory mechanisms is likely to be useful for breeding programs aiming to modify fruit flavonoid pattern.

\section{Keywords: anthocyanins, berries, flavonols, fruits, light, MYBs, proanthocyanidins, UV}

\section{INTRODUCTION}

Phenolic compounds constitute one of the most important groups of the bioactive compounds in food plants. These compounds possess diverse roles in signaling and defense in plants. In fruits and berries, flavonoids and hydroxycinnamic acids are the major phenolic compounds. Flavonoids are important determinants of quality and economic value of fruits as they have effect on color, aroma, astringency and antioxidant properties (He and Giusti, 2010). For example in grape berries (Vitis vinifera), flavonoid composition has effects on taste and quality of wine as well as conservation. Over 10,000 naturally occurring flavonoids have been described so far (Martens et al., 2010). The major flavonoid compounds present in flowers and fruits belong to flavonols, anthocyanins, and proanthocyanidins (PAs). Anthocyanin pigments are primary determinant of plant colors and serve as visual signals for pollinators in flowers and seed dispersers in ripe fruits. Flavonols have a role in photoprotection and they are generally considered to act as ultraviolet (UV) protectants and free-radical scavengers. PAs as astringent compounds can offer protection during the early stages of fruit development against herbivory and pathogen attack (Koes et al., 2005; Bogs et al., 2007).

Flavonoids are biosynthesized via the phenylpropanoid pathway and the key enzymes leading to different intermediates and different flavonoid classes are well known. At a molecular level, the biosynthesis of flavonoids is regulated via coordinated transcriptional control of the structural enzymes in the biosynthetic pathway by DNA binding R2R3 MYB transcription factors and, in many cases, interaction with MYC-like basic helix-loop-helix (bHLH) and WD40-repeat proteins (Hichri et al., 2011; Jaakola, 2013). Recent studies have revealed new upstream regulators of the pathway. In fruits, links between the key regulators of fruit development, SQUAMOSA- and SEPALLATA-class MADS box transcription factors, and anthocyanin biosynthesis have been shown in bilberry (Vaccinium myrtillus) and pear (Pyrus communis) (Jaakola et al., 2010; Wu et al., 2013).

The genetic background of the plant is the main determinant of the content of phenolic compounds in plant tissues, whereas external factors can cause qualitative or quantitative changes in the composition of these compounds. In many fruits, flavonols and PAs are the main flavonoids at the beginning of the fruit development and the accumulation of anthocyanin pigments is often an indicator of ripening. Fruits can be categorized into those which accumulate anthocyanins both in their skin and flesh, those which accumulate anthocyanins only in skin and those that accumulate anthocyanins in their skin only as response to light stimulus. In the first two classes, the developmental regulation of anthocyanin biosynthesis has a crucial role (Jaakola, 2013).

In climacteric fruits, the burst of plant hormone ethylene initiates the ripening process. In non-climateric fruits, such as grapevine, strawberry (Fragaria $\times$ ananassa), blueberry and bilberry (Vaccinium spp.), the plant hormone abscisic acid (ABA) seems to have a regulatory role both in ripening and initiation of anthocyanin biosynthesis (Wheeler et al., 2009; Jia et al., 2011; Zifkin et al., 2012; Karppinen et al., 2013). In addition to hormonal regulation, several studies have pointed that external 
factors, including temperature, light conditions, nutritional status and biotic stresses play a significant role in the accumulation of flavonoids in fruits (Koes et al., 2005; Jaakola and Hohtola, 2010; Azuma et al., 2012).

Several recent reviews have been dealing with the regulation of flavonoid biosynthesis in plants (e.g., Hichri et al., 2011; Falcone Ferreyra et al., 2012; Li, 2014). Different aspects of plant response to light have also been reviewed recently (e.g., Carvalho et al., 2011; Karpinski et al., 2013; Ballaré, 2014). In the present review, we focus on the role of light in the regulation of flavonoid biosynthesis in fruits.

\section{PROPERTIES OF LIGHT AND SOLAR RADIATION}

The solar irradiation reaching the earth's surface changes during the day and along the year. It is at highest around noontime, and shows higher peak between summer solstice and equinoxes, which coincides with the fruit ripening period of most of plant species. Photoperiod is not the same all over the globe as day length varies with the latitude. In northern areas, above $66^{\circ} \mathrm{N}$ latitude, the latitude of Murmansk-Russia, Rovaniemi-Finland, and Selawik Lake-Alaska, the sun remains continuously above the horizon in the summer, whereas at lower latitudes, for example $45^{\circ} \mathrm{N}$, the latitude of Milan-Italy, Ottawa-Canada and Queenstown-New Zealand, sun shines $16 \mathrm{~h}$ in the longest days of the year.

The electromagnetic spectrum of solar radiation stretches from gamma and X-rays at one extreme to radio waves at the other (Figure 1). The biologically active radiation consists of the spectrum from approximately 300 to $800 \mathrm{~nm}$ including UV-light (below $400 \mathrm{~nm}$ ). Visible light spectrum lays in the range between 400 and $710 \mathrm{~nm}$ and is subdivided in blue (400$495 \mathrm{~nm})$, green $(495-570 \mathrm{~nm})$, yellow $(570-590 \mathrm{~nm})$, and red (590-710 nm) wavelengths. At the extreme end of the visible spectrum, is far-red $(710-750 \mathrm{~nm})$ light, followed by the infrared radiation. The spectrum changes daily in terms of radiation intensity, while light quality is more stable. For instance, in a location nearby Trento (Italy, latitude $46^{\circ} \mathrm{N}$ ), our measures show that the relative amount of blue, red and far-red light reaching the earth's surface was constant throughout the day (between 9 am and $6 \mathrm{pm}$, during two consecutive weeks in June 2013). The measured visible light spectrum was composed by $17 \%$ of blue, $44 \%$ of green, $30 \%$ of red, and $9 \%$ of far-red light (Figure 2 ). This information is consistent with the earlier reports on the quality of the sun spectra (Robertson, 1966).

The quality of daily spectrum may vary, however, with the latitude as seen in our measurements (Figure 2). In the Arctic (latitude $69^{\circ} \mathrm{N}$ ), Taulavuori et al. (2010) recorded an increase of the relative amount of blue and far-red light components during the "night hours" on summer solstice, while the relative proportion of red light decreased. In the Southern hemisphere, for instance New Zealand (latitude $45^{\circ} \mathrm{S}$ ) receives $40 \%$ higher levels of UV radiation compared to similar latitudes in the Northern hemisphere (McKenzie et al., 2006; Gregan et al., 2012), and in Southern Chile (at latitude $39^{\circ} \mathrm{S}$ ), and Australia (latitude $38^{\circ} \mathrm{S}$ )

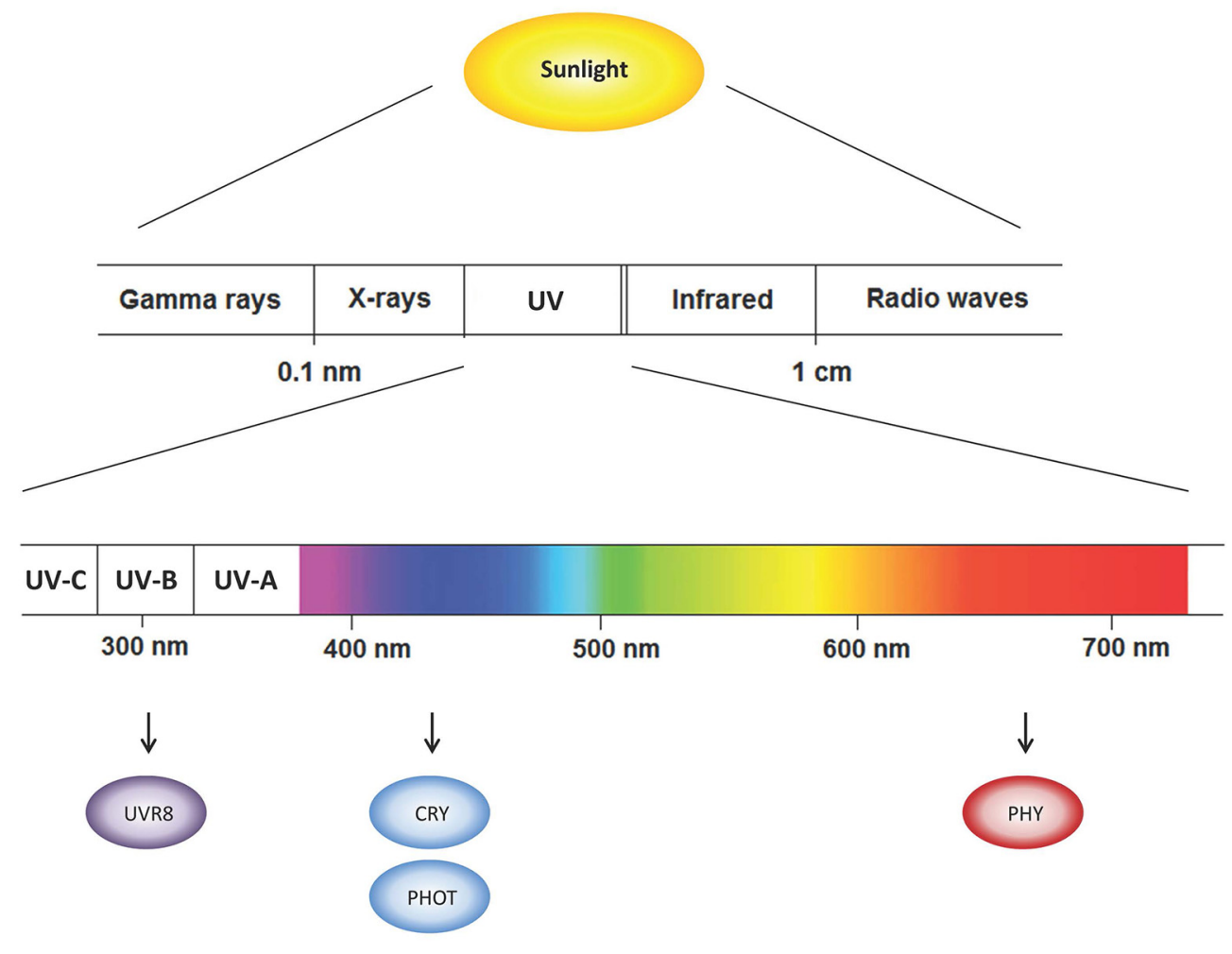

FIGURE 1 | The spectrum of solar radiation reaching from gamma rays to radio waves with closer view on visible wavelengths and plant photoreceptors absorbing specific wavelength regions. Cry, cryptochromes; Phy, phytochromes; Phot, phototropins; UV, ultraviolet; UVR8, UV-B photoreceptor. 


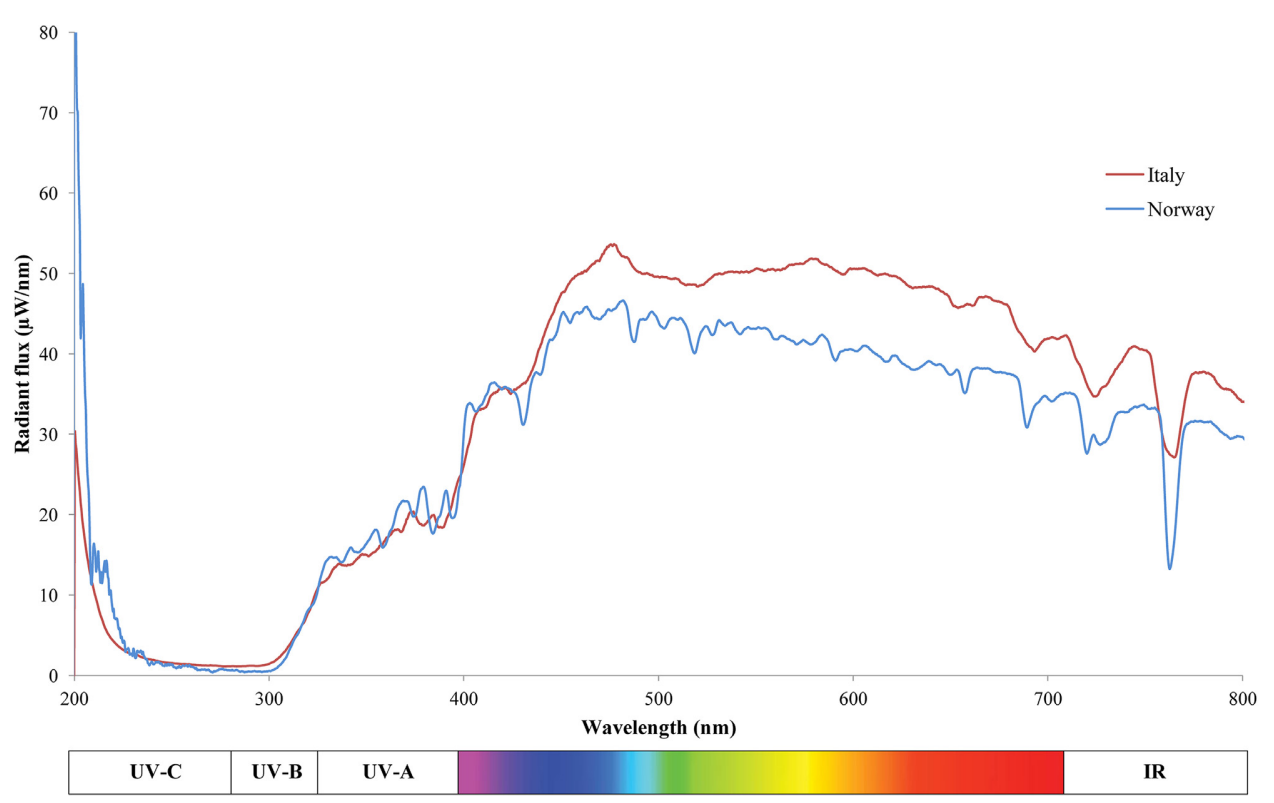

FIGURE 2 | Summer solar radiant flux spectra of two European locations (Tromsø, Norway, latitude $69^{\circ} \mathrm{N}$, longitude $18^{\circ} \mathrm{E}$; Trento, Italy, latitude $46^{\circ} \mathrm{N}$, longitude $11^{\circ} \mathrm{E}$ ) under clear sky and midday conditions. Troms $\varnothing$ UV-B $(280-320 \mathrm{~nm}): 0.71 \mu$ joule $\mathrm{cm}^{-}$; UV-A $(320-400 \mathrm{~nm}): 12.37 \mu$ joule $\mathrm{cm}^{-2}$ :
$\operatorname{PAR}_{(400-700 \mathrm{~nm})}: 1389 \mu$ moles photones $\mathrm{m}^{-2} \mathrm{~s}^{-1}$. Trento UV-B $(280-320 \mathrm{~nm})$ : $2.29 \mu$ joule $\mathrm{cm}^{-2}$; UV-A $(320-400 \mathrm{~nm}): 45.5 \mu$ joule $\mathrm{cm}^{-2}$ : $\operatorname{PAR}_{(400-700 \mathrm{~nm})}$ : $3670 \mu$ moles photones $\mathrm{m}^{-2} \mathrm{~s}^{-1}$. IR, infrared; PAR, photosynthetic active radiation. the received UV radiation can be even higher (Huovinen et al., 2006).

\section{PERCEPTION OF LIGHT BY PLANTS}

The ability to perceive and transduce light signal is important for optimal growth and development of sessile plants. Plants are reliant on sunlight as their source of energy and they are able to sense the different aspects of light in their growth environment including light intensity, direction, specific wavelengths and photoperiod. Plants employ a complex array of photoreceptors to coordinate their response to the ambient light environment (e.g., Wagner et al., 2005). In addition to chlorophylls and carotenoids in light-harvesting complexes participating in photosynthesis, higher plants utilize multiple sensory photoreceptors to accurately perceive light conditions ranging from UV-B to far-red wavelengths (Möglich et al., 2010; Rizzini et al., 2011). Principal among these is the phytochrome superfamily including photoreceptors absorbing red/far-red light (PHYA, PHYB, PHYC, PHYD, PHYE) as well as cryptochromes (CRY1, CRY2, CRY3), and phototropins (PHOT1, PHOT2) sensing UV-A/blue light, and UV-B photoreceptor UV RESISTENCE LOCUS8 (UVR8) that has been recently identified (Favory et al., 2009; Rizzini et al., 2011; Casal, 2013) (Figure 1). Upon light absorption, these photoreceptors activate various signal transduction cascades to regulate light-dependent responses and related gene expression in plants.

For light sensing and signaling, phytochromes consist of a bilin chromophore bonded to the protein moiety. In flowering plants, LONG HYPOCOTYL 2 (HY2) is the only ferredoxindependent bilin reductase (FDBR) producing the phytochromobilin for phytochromes. It has been shown that mutations in HY2 gene cause the loss of all photoactive phytochromes in plants and furthermore lead to disruption in photomorphogenesis (Kohchi et al., 2001; Chen et al., 2012). Phytochromes exist in two different interconvertible forms; $\mathrm{P}_{r}$ that absorbs red light and far-red light absorbing $\mathrm{P}_{\mathrm{fr}}$. Phytocromes are synthesized in the dark in the $\mathrm{P}_{\mathrm{r}}$ form and following the conversion to the $\mathrm{P}_{\mathrm{fr}}$ form, they move to the nucleus. Red light $(660 \mathrm{~nm})$ causes conversation of $P_{r}$ to biologically active $\mathrm{P}_{\mathrm{fr}}$ form and far-red light $(730 \mathrm{~nm})$ the conversation back to $\mathrm{P}_{\mathrm{r}}$ form. $\mathrm{P}_{\mathrm{fr}}$ can also be degraded in the proteasome after ubiquitination if not back-reverted to $\mathrm{P}_{\mathrm{r}}$. Under white light containing both red and far-red wavelengths, photoequilibrium is established after few minutes. The different forms allow phytochrome to function as a biological switch, turning responses on and off enabling the detection of circadian rhythms and seasonal changes in light conditions (Reed, 1999; Casal, 2013).

Cryptochromes are flavin-containing photoreceptors for blue, green and UV-A light perception. Cryptochromes are involved in sensing circadian rhythms and regulation of many developmental and adaptive processes including biosynthesis of secondary metabolites, such as flavonoids (Giliberto et al., 2005; Lopez et al., 2012). Also blue and UV-A light absorbing phototropins have been shown to be involved in phototropism and blue lightinduced chloroplast migration and stomatal opening (Briggs and Christie, 2002). Recent findings have shown that phototropins also play a role in blue light-mediated changes in biosynthesis of secondary metabolites (Kadomura-Ishikawa et al., 2013).

\section{EFFECT OF LIGHT INTENSITY ON FLAVONOID BIOSYNTHESIS IN FRUITS}

Numerous fruit bagging and shading experiments have shown the importance of light conditions on the biosynthesis and accumulation of flavonoids. Exclusion of fruits from sunlight 
has in many cases been demonstrated to lead suppressed expression of flavonoid pathway genes resulting in decreased amounts of flavonoid compounds in both climacteric and nonclimacteric fruits. For example in pericarp of non-climacteric litchi (Litchi chinensis), fruit bagging treatments have been shown to inhibit accumulation of anthocyanins as well as expression of anthocyanin biosynthetic genes chalcone synthase ( $\mathrm{LcCHS}$ ), chalcone isomerase $(\mathrm{LcCHI})$, flavanone 3-hydroxylase $(\mathrm{LcF} 3 \mathrm{H})$, dihydroflavonol 4-reductase ( $L c D F R)$, anthocyanidin synthase (LcANS), and UDP-glucose: flavonoid 3-O-glucosyltransferase $(L c U F G T)$ that were again up-regulated accompanied by elevated anthocyanin accumulation after debagging and exposure the fruits to sunlight (Wei et al., 2011).

Extensive studies have been carried out on the effect of light conditions on fruit flavonoid composition in non-climacteric grapevine fruits. The studies demonstrate that grape berries adapt to high light by elevating the expression of an array of both early and late flavonoid biosynthetic genes in berry skin which leads in the increased content of anthocyanins, PAs as well as flavonols (Jeong et al., 2004; Cortell and Kennedy, 2006; Fujita et al., 2006; Pereira et al., 2006; Matus et al., 2009; Azuma et al., 2012; Koyama et al., 2012). In the study of Azuma et al. (2012), light treatment led to significantly higher total anthocyanin content in grape berry skin compared to dark grown berries, and induced higher expression levels of $\mathrm{CHS}, \mathrm{CHI}, \mathrm{F} 3 \mathrm{H}$, flavonoid $3^{\prime}, 5^{\prime}$-hydroxylase $\left(F 3^{\prime} 5^{\prime} H\right)$, DFR, O-methyltransferase $(O M T)$ as well as UFGT. Exposure to light was shown to increase anthocyanin concentrations in grape berry skin regardless of ambient temperature (Spayd et al., 2002; Azuma et al., 2012). Especially flavonol levels seem to be sensitive to changes in light conditions in grape berries, as highly induced accumulation of flavonols along with increased expression of flavonol synthase (FLS), has been reported by light exposure in different cultivars such as Shiraz (Downey et al., 2004), Merlot (Fujita et al., 2006), Cabernet Sauvignon (Fujita et al., 2006; Matus et al., 2009; Koyama et al., 2012) as well as Pione (Vitis $\times$ labruscana, Azuma et al., 2012).

Positive effects of light on flavonoid biosynthesis has also been reported in many other fruit species including Chinese bayberry (Myrica rubra, Niu et al., 2010), cranberry (Vaccinium macrocarpon, Zhou and Singh, 2004), bilberry (Uleberg et al., 2012), raspberry (Rubus idaeus, Wang et al., 2009a), and tomato (Solanum lycopersicum, Løvdal et al., 2010). In Chinese bayberry, anthocyanins are responsible for the red coloration in the presence of light, and bagging of the fruits has been shown to reduce anthocyanin amount to $0.5 \%$ of that of non-bagged fruits (Niu et al., 2010).

Light has also been recognized as an important regulator of flavonoid accumulation in species of Rosaceae family such as strawberry (Fragaria $\times$ ananassa, Anttonen et al., 2006; Kadomura-Ishikawa et al., 2013), peach/nectarine (Prunus persica, Jia et al., 2005; Ravaglia et al., 2013), pear (Pyrus pyrifolia, Feng et al., 2010; Sun et al., 2014), and apple (Malus $\times$ domestica, Takos et al., 2006a,b; Feng et al., 2013). In the apple skin, sunlight is the most important environmental factor inducing flavonoid biosynthesis, especially anthocyanin and flavonol biosynthesis, and fruits with sun-exposed peel have higher levels of anthocyanins and flavonols than those grown in shade (Feng et al.,
2013; Li et al., 2013). Exposure of shaded fruit skin to sunlight has been demonstrated to lead up-regulation of flavonol biosynthetic gene MdFLS and several anthocyanin biosynthetic genes, including $M d C H S, M d C H I, M d F 3 H, M d D F R 1$, leucoanthocyanidin dioxygenase (MdLDOX) and MdUFGT (Feng et al., 2013; Vimolmangkang et al., 2014). The elevated expression of flavonoid biosynthetic genes was accompanied by increased levels of anthocyanins, flavonols, and total phenolics (Feng et al., 2013). It has been shown that exposure of bagged apple fruits to light can cause increase in $\mathrm{MdCHI}$ transcription level by even up to 240fold, accompanied by MdCHS and MdLDOX at 80- and 60-fold, respectively, (Takos et al., 2006b). In fact, in many apple cultivars light exposure is required to stimulate anthocyanin biosynthesis and desirable red skin coloration (Takos et al., 2006a; Feng et al., 2013) and also post-harvest light treatment has been shown to have highly positive influence on apple peel anthocyanin and flavonol contents (Hagen et al., 2007).

The rapid induction of flavonoid biosynthesis that is generally observed under high light conditions reflects the important role of flavonoids in photoprotection. However, in some fruit species flavonoid biosynthesis is less affected by light. In tropical mangosteen (Garcinia mangostana) fruit, anthocyanin accumulation is unaffected by light (Palapol et al., 2009) and high light can even decrease anthocyanin biosynthesis in pears (Zhang et al., 2011). Moreover, all fruits do not require strong light exposure to accumulate high amounts of flavonoids. For example, bilberry is one of the best sources of anthocyanins although prefers shaded growth habitats and thus anthocyanin accumulation is under strong developmental control (Jaakola et al., 2004). In these kinds of fruits, the spatiotemporal regulation directs the biosynthesis of different classes of flavonoids at different stages of fruit development and environmental factors have only fine-tuning affect. It has been shown that anthocyanin levels are affected more by fruit developmental stages whereas flavonols and PAs are more sensitive to environmental factors (Carbone et al., 2009). For example, flavonol biosynthesis can be induced by light exposure at such stages of grape berry development when flavonols are not normally accumulated (Downey et al., 2004; Matus et al., 2009).

Flavonoid biosynthesis also seems to be influenced by light in a cultivar-specific manner. For instance, among grapevines, sunlight induces both anthocyanin and flavonol accumulation in Cabernet Sauvignon (Matus et al., 2009) while only flavonol production is induced in Shiraz grapes (Downey et al., 2004). Different ability to accumulate anthocyanins under light exclusion between two grape cultivars (Jingyan and Jingxiu) was shown to be related to differences in expression of UFGT (Zheng et al., 2013). Also in apple, centuries of intensive breeding has provided red and yellow/green cultivars with varying response to lightstimulated anthocyanin biosynthesis (Feng et al., 2013). Cultivars differing in their sensitivity to light in the induction of flavonoid biosynthesis have also been reported in sweet cherry (Prunus avium, Kataoka et al., 2005) and plum (P. salicina, Murray et al., 2005), tomato (Giuntini et al., 2008) as well as in pear (Zhang et al., 2011; Qian et al., 2013). Many fruit species also have white varieties in which light do not stimulate anthocyanin production, due to mutations in structural or regulatory genes of flavonoid pathway. These kinds of mutations have been reported 
for example in grape berries (Kobayashi et al., 2004; Walker et al., 2007), strawberry (Salvatierra et al., 2010), Chinese bayberry (Niu et al., 2010), and bilberry (Jaakola et al., 2002, 2010), and these mutants have had an important role when revealing the regulatory genes involved in the flavonoid biosynthetic pathway.

\section{REGULATION OF FRUIT FLAVONOID BIOSYNTHESIS BY LIGHT}

During recent years our knowledge on regulation of flavonoid biosynthesis in fruits has significantly increased through identification of the key transcription factors and genome sequencing of important flavonoid accumulating fruit crops such as grapevine, apple, peach and strawberry (Jaillon et al., 2007; Velasco et al., 2010; Shulaev et al., 2011; Verde et al., 2013). These studies indicate that the R2R3 MYB transcription factors, which directly affect the expression of the structural flavonoid biosynthesis genes, are the primary regulators of fruit flavonoid biosynthesis and have been recently reviewed also in the case of fruit bearing species (Allan et al., 2008; Petroni and Tonelli, 2011; Czemmel et al., 2012; Jaakola, 2013).

The R2R3 MYB transcription factors coordinately regulate flavonoid structural genes by activating or repressing their expression. Recently, R2R3 MYB transcription factors associated with flavonoid biosynthesis have been identified and characterized in several fruit producing species and some of them have been found to respond to light. Light-inducible R2R3 MYB transcription factors controlling flavonoid biosynthesis in fruits have been identified in apple, pear, nectarine, Chinese bayberry, strawberry, litchi, and grapevine (Table 1). In changing light conditions, the expression level of these R2R3 MYB transcription factors is adjusted to regulate the biosynthesis of distinct flavonoid compounds.

In grapevine, intensive studies have led to identification of multiple R2R3 MYB transcription factors and at the same time shown that the regulation of flavonoid biosynthesis through these factors forms a complex network (reviewed in Czemmel et al., 2012). Various R2R3 MYB transcription factors of grapevine can regulate same branch in flavonoid biosynthetic route but one transcription factor can also regulate both early and late biosynthetic genes and be affected by cues from both developmental and environmental signals (Czemmel et al., 2012; Lai et al., 2013). In grapevine, light has been demonstrated to induce expression of an array of R2R3 MYB transcription factors that are positive regulators of general flavonoid pathway $(V v M Y B 5 a)$ as well as those specifically responsible for anthocyanin ( $V v M Y B A 1, V v M Y B A 2)$, flavonol ( $V v M Y B F 1$, $V v M Y B 12)$, and PA (VvMYBPA1, VvMYBPA2) biosynthesis (Table 1). Contradictory results of light-regulation of $V v M Y B 5 b$ have been reported (Matus et al., 2009; Azuma et al., 2012; Koyama et al., 2012). However, VvMYB4, a repressor of anthocyanin biosynthesis, has not been found to respond light (Matus et al., 2009; Azuma et al., 2012). In fact, none of the so far identified R2R3 MYB transcription factors that have role as a

Table 1 | Identified light-inducible R2R3 MYB transcription factors regulating flavonoid biosynthesis in fruit producing species.

\begin{tabular}{|c|c|c|c|}
\hline Species & R2R3 MYB & Function & References \\
\hline \multirow[t]{5}{*}{ Apple (Malus $\times$ domestica) } & MdMYB1 & Anthocyanin biosynthesis in fruit skin & Takos et al., 2006a \\
\hline & MdMYBA & Anthocyanin biosynthesis in fruit skin & Ban et al., 2007 \\
\hline & MdMYB10 & Anthocyanin biosynthesis in fruit skin & Feng et al., 2013 \\
\hline & MdMYB9 & Proanthocyanidin biosynthesis in leaves & Gesell et al., 2014 \\
\hline & MdMYB11 & Proanthocyanidin biosynthesis in leaves & Gesell et al., 2014 \\
\hline Chinese bayberry (Myrica rubra) & MrMYB1 & Anthocyanin biosynthesis in fruit & Niu et al., 2010 \\
\hline \multirow[t]{8}{*}{ Grape (Vitis vinifera, Vitis × labruscana) } & VvMYBF1 & Flavonol biosynthesis in fruit skin & Czemmel et al., 2009; Azuma et al., 2012 \\
\hline & VvMYB12 & Flavonol biosynthesis in fruit skin & Matus et al., 2010; Liu et al., 2014 \\
\hline & VvMYBA1 & Anthocyanin biosynthesis in fruit skin & $\begin{array}{l}\text { Jeong et al., 2004; Matus et al., 2009; } \\
\text { Azuma et al., 2012; Koyama et al., } 2012\end{array}$ \\
\hline & VIMYBA2 & Anthocyanin biosynthesis in fruit skin & Azuma et al., 2012 \\
\hline & VvMYBPA1 & Proanthocyanidin biosynthesis in fruit skin & Azuma et al., 2012; Koyama et al., 2012 \\
\hline & VvMYBPA2 & Proanthocyanidin biosynthesis in fruit skin & Koyama et al., 2012 \\
\hline & VvMYB5a & General flavonoid biosynthesis in fruit skin & Matus et al., 2009; Koyama et al., 2012 \\
\hline & VIMYB5b & General flavonoid biosynthesis in fruit skin & Azuma et al., 2012 \\
\hline Litchi (Litchi chinensis) & LcMYB1 & Anthocyanin biosynthesis in fruit pericarp & Lai et al., 2014 \\
\hline
\end{tabular}

\begin{tabular}{|c|c|c|c|}
\hline Nectarine (Prunus persica) & PpMYB10 & Anthocyanin biosynthesis in fruit skin & Ravaglia et al., 2013 \\
\hline Pear (Pyrus pyrifolia) & PyMYB10 & Anthocyanin biosynthesis in fruit skin & Feng et al., 2010; Zhang et al., 2011 \\
\hline Cultivated strawberry (Fragaria $\times$ ananassa) & FaMYB10 & Anthocyanin biosynthesis in fruit & Miyawaki et al., 2012 \\
\hline
\end{tabular}

Woodland strawberry (Fragaria vesca) FvMYB10 Anthocyanin biosynthesis in flower petal Lin-Wang et al., 2010 
repressor of flavonoid biosynthesis in fruits have been reported to respond to light. For example in flower petals of woodland strawberry (Fragaria vesca), high light induced expression of positive regulator $F v M Y B 10$ but not $F v M Y B 1$, a repressor of anthocyanin biosynthesis (Lin-Wang et al., 2010).

Most of the identified R2R3 MYB transcription factors of flavonoid biosynthesis seem to interact with bHLH and WD40repeat proteins to form MBW regulatory complex. The role of bHLH and WD40 partners in light-regulated flavonoid biosynthesis is not yet clear. Matus et al. (2009) did not found expression of either MYCA1 or WDR1 to change by influence of light exposure in grapevine, although these genes seem to have a role in other types of stresses (Matus et al., 2010). Zhang et al. (2011) got contradictory results from the expression of bHLH and WD40 partners between two pear cultivars exposed to light. It has earlier been proposed that the MYB partner of the MBW complex would be more directly involved in the light-mediated regulation of flavonoid biosynthesis than bHLH or WD40 partners that would mostly have a co-operative role in the process (Hartmann et al., 2005; Matus et al., 2009, 2010). Recently, bHLH3 but not WD40 of the regulators of flavonoid biosynthesis in nectarine, was shown to be up-regulated after light treatment (Ravaglia et al., 2013), and light-inducible bHLH was suggested as regulator of anthocyanin biosynthesis in apple fruit exocarp (Vimolmangkang et al., 2014).

R2R3 MYB transcription factors mediate direct and specific interaction with MYB recognition element (MRE) that is present in the promoters of the structural target flavonoid genes. The MRE has been found to be necessary for light-induced expression of the structural flavonoid genes, such as CHS (Feldbrügge et al., 1997). Hartmann et al. (2005) showed that the MRE present in promoter of Arabidopsis CHS is part of the light regulatory unit (LRU) that is needed for light-mediated induction of CHS. Since then, LRUs as well as other light-responsive elements have been reported not only in promoters of flavonoid structural genes, such as MdDFR and MdUFGT in apple (Takos et al., 2006a), VvFLS1 in grapevine (Czemmel et al., 2009), and many structural anthocyanin biosynthetic genes of peach (Zhou et al., 2013) but also promoters of R2R3 MYB transcription factors of grapevine $V v M Y B F 1$, litchi LcMYB1 (Lai et al., 2014) and pear PyMYB10 (Feng et al., 2010). In addition that the presence of LRU in the promoter is an indicator of the light responsiveness of the gene, it also contains bZIP recognition element (ACE). Today, the signaling pathway from light perception to flavonoid biosynthesis through R2R3 MYB transcription factors to induce biosynthesis of specific flavonoid compounds in fruits is not well understood. However, it has been proposed that bZIP transcription factors have a role in this process (Hichri et al., 2011). The involvement of bZIP transcription factor regulating the expression of R2R3 MYB transcription factor attending to flavonoid biosynthesis in fruit was demonstrated recently for the first time when bZIP transcription factor was shown to regulate PA biosynthesis in persimmon (Diospyros kaki) fruit (Akagi et al., 2012).

Recently, an important piece of the puzzle in the mechanism by which light controls anthocyanin biosynthesis in fruits at post-translational level was reported. Li et al. (2012) demonstrated that in apple, the MdMYB1 protein, a positive regulator of light-induced anthocyanin biosynthesis, interacts directly with MdCOP1 protein that negatively modulates abundance of the MdMYB1. The RING-finger type ubiquitin E3 ligase CONSTITUTIVE PHOTOMORPHOGENIC1 (COP1) acts as a negative regulator of light signaling directly at the downstream of the photoreceptors and control different light-regulated plant development processes by adjustment of its subcellular localization (Lau and Deng, 2012). The physical proteinprotein interaction of COP1 with phytochromes, cryptochomes and phototropins has been demonstrated in Arabidopsis (Jang et al., 2010; Jeong et al., 2010; Liu et al., 2011). In the dark, COP1/SUPPRESSOR OF PHYA (SPA) complex is localized in the nucleus, where it interacts with the subset of specific key positive regulators mediating their ubiquitination and degradation via the $26 \mathrm{~S}$ proteasome pathway (Figure 3A). Ubiquitination involves covalent attachment of ubiquitin polypeptides to target protein, which are subsequently marked for degradation by $26 \mathrm{~S}$ proteasome that mediates proteolysis of target protein (Vierstra, 2009). In light, COP1/SPA complex interacts with activated photoreceptors leading to the inhibition of COP1/SPA function by dissociation of COP1 from the complex and exportation from the nucleus (Figure 3B). Low abundance of COP1 in nucleus allows nuclear-localized transcription factors to accumulate and induce gene expression (Lau and Deng, 2012).

Among COP1 targeted transcription factors, ELONGATED HYPOCOTYL5 (HY5), a bZIP transcription factor promoting photomorphogenesis (Lee et al., 2007), is a direct target of COP1. HY5 becomes stabilized in light when the COP1 protein is removed from nucleus (Figure 3B). HY5 has also been linked to activation of the R2R3 MYBs and key structural genes of the flavonoid pathway as well as the accumulation of flavonoids in response to light in Arabidopsis and apple (Hardtke et al., 2000; Stracke et al., 2010; Maier et al., 2013; Peng et al., 2013; Shin et al., 2013). However, other yet unidentified more rapid mechanism mediating COP1 signal from phytochomes and cryptochromes have been proposed since export of COP1 from nucleus is rather slow $(24 \mathrm{~h})$ and thus allows transcription factors to accumulate only at extended light conditions (Lau and Deng, 2012). Yet accumulation of HY5 and light-induced expression of flavonoid pathway genes can be seen rapidly within few hours (Cominelli et al., 2008; Li et al., 2010).

Mutations in COP1/SPA complex has been shown to lead in increased accumulation of anthocyanins in Arabidopsis (Maier et al., 2013) and mutation in light signaling machinery has been shown to have effects on flavonoid biosynthesis also in fruits. Tomato $h p$ mutants, characterized by exaggerated light responsiveness, overproduce several flavonoid compounds in mature fruits (Azari et al., 2010). Furthermore, additional mutation in ANTHOCYANIN FRUIT ( $A F T$ ), gene encoding MYB transcription factor, in tomato $h p$ mutant positively affects fruit flavonoid content (Azari et al., 2010). Also inactivation of DEETIOLATED1 (DET1), a photomorphogenesis regulating gene, has been shown to lead to a significant increase in flavonoid content in tomato fruit (Davuluri et al., 2005).

The regulation of anthocyanin biosynthesis has recently been suggested to be closely linked with other protective processes 


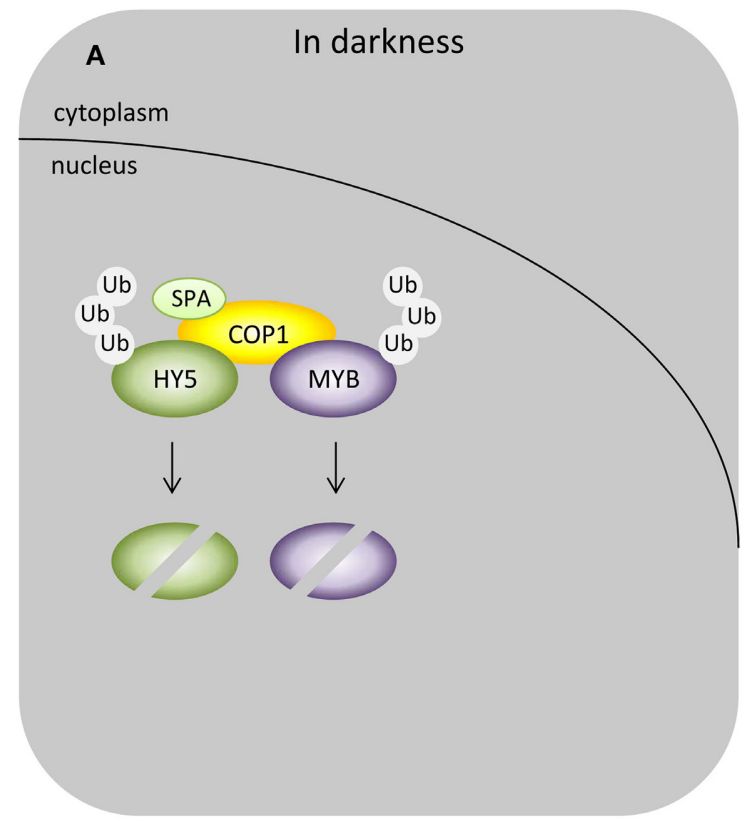

FIGURE 3 | COP1 acts as a central repressor in light signaling pathway by interacting directly with photoreceptors to mediate different light-regulated plant developmental processes. (A) In darkness, nuclear localized COP1 targets positive regulators, such as transcription factors HY5 and R2R3 MYBs, for ubiquitination and subsequent protein degradation through a $26 \mathrm{~S}$ proteasome pathway. (B) In visible light, interaction with activated photoreceptors repress function

\section{B In visible light}

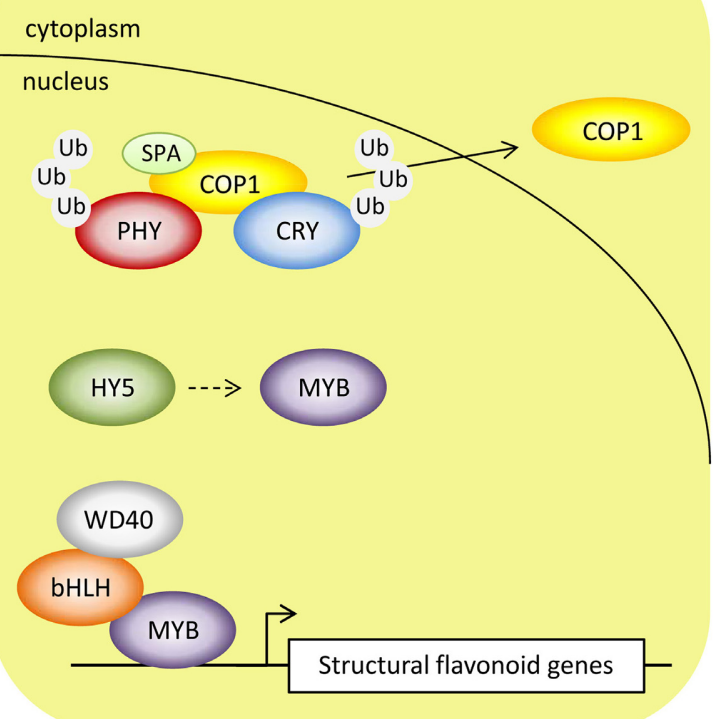

of COP1 that is subsequently exported from nucleus allowing nuclear-localized transcription factors to accumulate and induce gene expression in light-regulated processes. The expression of structural flavonoid genes is directly regulated by R2R3 MYB transcription factors which may be regulated by bZIP transcription factor such as HY5. During the process, photoreceptors are ubiquitinated by COP1 and targeted for degradation (Lau and Deng, 2012). against high light. Shading experiments with peach leaves by Zhou et al. (2013) demonstrated simultaneous reduction in anthocyanin biosynthesis with the increase in expression of photorespiratory genes. Also high expression level of photorespiratory genes in Arabidopsis $\mathrm{CHI} / \mathrm{F3}^{\prime} \mathrm{H}$ mutant, that are unable to accumulate anthocyanins, suggest that photorespiration-related genes may be involved in the regulation of anthocyanin biosynthesis but the mechanism is so far unknown (Zhou et al., 2013).

\section{EFFECT OF LIGHT QUALITY ON FLAVONOID BIOSYNTHESIS IN FRUITS \\ VISIBLE LIGHT WAVELENGTHS}

The accumulation of fruit flavonoids is also sensitive to the quality of the light spectrum received by the plant. It appears that shorter wavelengths, in the range of blue and UV-light show the most prominent effect in the accumulation of flavonoids in fruits, often by increasing the expression of flavonoid pathway genes. In unripe strawberries, blue light increased significantly the biosynthesis of anthocyanins and the expression of $\mathrm{FaCHS}$ after four days of treatment (Kadomura-Ishikawa et al., 2013). In grape berries treated with light emitting diode (LED) light, anthocyanin concentrations were highest in blue light-treated skin, followed by red light treatment (Kondo et al., 2014). In the same study, differences in anthocyanin profile were also detected and especially malvidin-glycosides increased toward harvest in blue and red LED-treated skin, unlike in untreated controls. In this case however, the transcript levels of VIMYBA1-2, VIMYBA2, and VvUFGT did not necessarily coincide with anthocyanin concentrations. These findings have increased the interest toward the application of led lights in fruit orchards in order to improve fruit quality at ripeness in terms of nutritional value and content of bioactive compounds.

The relevance of blue light perception through phototropins in flavonoid biosynthesis has recently been demonstrated at molecular level in strawberry, when expression of phototropin 2, FaPHOT2, was shown to elevate during berry development and correspond to increase in anthocyanin content (KadomuraIshikawa et al., 2013). Furthermore, in the same study knockdown of FaPHOT2 resulted in decreased anthocyanin content while overexpression increased accumulation of anthocyanins in strawberry fruit. Also, the overexpression of blue light sensing cryptochrome in tomato (Giliberto et al., 2005) resulted in the accumulation of anthocyanins in tomato fruits.

Interestingly, the accumulation of flavonoid compounds in response to light has been shown to continue in post-harvest fruits. Total anthocyanin content of strawberry fruits significantly increased after four days of treatment with blue light $\left(40 \mu \mathrm{mol} \mathrm{m} \mathrm{m}^{-2} \mathrm{~s}^{-1}\right)$ at $5^{\circ} \mathrm{C}$ compared to the control fruits $(\mathrm{Xu}$ et al., 2014). Meanwhile, the treatment also increased the activities of the enzymes of the general phenylpropanoid and flavonoid pathway including glucose-6 phosphatase (G6PC) phenylalanine ammonialyase (PAL), cinnamate-4-hydroxylase $(\mathrm{C} 4 \mathrm{H})$, 4coumarate: coenzyme A ligase (4CL), CHS, F3H, DFR, ANS, and UFGT. Therefore, a supplemental blue light source might increase 
anthocyanin content in strawberries also during fruit storage. These results are important as they indicate that the physiological response to light stimulus is located in the fruit.

\section{UV-LIGHT}

Solar UV radiation reaching the earth's surface is composed of UV-A (320-400 nm) and part of UV-B (280-320 nm) while most of the UV-B and all UV-C ( $<280 \mathrm{~nm})$ radiation is absorbed by the ozone layer. Over the last decades, depletion in ozone layer has increased the level of solar UV-B radiation reaching the earth and now approximately $0.5 \%$ of total solar light radiation accounts from UV-B (Heijde and Ulm, 2012). Although UV-B represents only a small fraction of total solar spectrum, it has extensive photobiological effects on plants inducing changes in photosynthesis, cell division and other life processes that affect growth and development of plants (Jansen et al., 1998; Cockell and Knowland, 1999; Sullivan and Rozema, 1999; Hollósy, 2002; Kakani et al., 2003; Brown et al., 2005; Mpoloka, 2008).

Stress caused by UV-B light is known to enhance the production of reactive oxygen species (ROS) damaging DNA, proteins and photosynthetic apparatus in plants, but these effects are dose and phenotype dependent (Smith et al., 2000; Frohnmeyer and Staiger, 2003). Some flavonoids, especially flavonols, are reported to be highly effective scavengers of ROS as well as selectively absorbing UV-B radiation (Falcone Ferreyra et al., 2012). Therefore, it is not surprising that flavonoid production in plants is strongly induced by light and UV-B wavelengths. Many flowers and fruits produce flavonols, flavones, and anthocyanins as response to excess UV-light. However, the mechanisms involved in the induction of these metabolites need to be discussed in terms of the resistance and acclimation of plants.

The effects of UV-light in plants have been studied actively since late 1970s' when the depletion in the ozone layer was discovered in the polar regions (Farman et al., 1985). Still, the future of the earth's UV climate is uncertain (Andrady et al., 2010) emphasizing the importance of the topic especially for agriculture affecting the yield and quality of crop plants including fruits. In addition to UV-light effects under natural growth conditions, post-harvest treatments with UV-light have been performed to improve fruit quality. Most of these studies have been carried out with UV-C radiation, which is more energetic and can rapidly decrease the incidence of pathogens in fruits (Stevens et al., 1996; Allende and Artés, 2003). UV-B radiation has been applied postharvest with the special purpose to increase the contents of health beneficial secondary metabolites.

\section{Natural UV-light}

The effect of natural UV-B radiation on the biosynthesis of flavonoids was studied in an experiment where Cabernet Sauvignon grape berries were cultivated under UV-shield (Koyama et al., 2012). A high decrease in the content of flavonols was detected in the skin of grape berries (under UV-shield), whereas levels of PAs and cinnamic acids were less affected. Additional experiment under artificial white light compared with white light together with supplemental UV-light revealed that UV-light did not markedly affect the levels of PAs in grape berry skin. The transcript levels of analyzed flavonoid pathway genes were consistent with metabolite results and a decrease in VvFLS4 transcript abundance was detected in berry skin samples under UV-shield (Koyama et al., 2012).

Liu et al. (2014) reported the effect of natural UV-B radiation related biosynthesis on flavonoid biosynthesis in white Sauvignon blanc grape berries. The experiment was conducted in New Zealand, where the natural UV radiation levels are high compared with corresponding latitudes in Northern hemisphere, using A-frame-mounted UV-transmitting/excluding screens covering only the fruiting zone of the plants. Substantial increase in the levels of flavonols, particularly quercetin and kaempferol glycosides was detected upon fruit exposure to UV-B (Table 2). Of five $V v F L S$ genes of grapevines, two were found to be transcriptionally active, and only one (VvFLS4) was responsive to UV-B. Of the related transcription factors ( $V v M Y B 12, V v M Y C A 1$, $V v W D R s)$, only $V v M Y B 12$ was found to be responsive to UV$B$. In the same study, other candidate genes associated with low and high UV-B fluence responses ( $V v U V R 8, V v H Y 5, V v C O P 1$, $V v C H S$ ) showed variable results.

Similarly to other photoreceptors, signaling of the UV-B absorbing photoreceptor UVR8 is also mediated through COP1. Contrary to the role of COP1 in visible light, under UV-B irradiation Arabidopsis COP1 has been shown to act as a positive regulator by interacting with UVR8 and promote through an unknown mechanism the expression of HY5 (Lau and Deng, 2012; Figure 4). In the process, UVR8 changes from a dimer to monomer to interact with COP1. The recent results have given evidence on the function of the same mechanism mediating the responses of the UV-B radiation also in apple (Peng et al., 2013). In grape berries, $V v U V R 8$ did not respond to UV-B but instead showed fruit development related changes having significantly higher expression at pre-veraison compared to post-veraison (Liu et al., 2014). This result is consistent with previous findings in Arabidopsis showing that UVR8 does not respond to different light qualities (Kaiserli and Jenkins, 2007). In contrast, VvHY5 did show a significant up-regulation by UV-B light as well as $\mathrm{VvCHS1}$ and $V v C H S 2$. The results suggested that flavonol biosynthesis in grape is stimulated predominantly through the low fluence UV-B response pathway (Liu et al., 2014). It is notable that more than $98 \%$ of the UV-light reaching the earth's surface correspond to $\mathrm{UV}-\mathrm{A}$ radiation. There has been suggestions of the existence of specific photoreceptor for UV-A, different than UVR8, but it still remains uncertain (Zhou et al., 2007; Guo and Wang, 2010; Wang et al., 2012).

\section{Pre- and post-harvest studies with supplemental UV-light}

The effect of supplemental UV-light treatments on the content of phenolic compounds has been evaluated in various fruit crops, often with the aim of developing techniques to increase healthpromoting potential of the fruits and indirectly improve the aesthetic value with higher anthocyanin content. The changes in the content of phenolic compounds in response to UV-light vary between species. Early pre-harvest studies showed the enhancement of anthocyanin levels as response to UV irradiation in apple (Arakawa et al., 1985) and sweet cherry skin (Arakawa, 1993; Kataoka et al., 1996). More recently, UV-B irradiation treatment has been shown to increase the anthocyanin content and the 
Table 2 | Main responses of flavonoid compounds under UV-light exposition in fruits.

\begin{tabular}{|c|c|c|c|c|c|}
\hline Species & Tissue & $\begin{array}{l}\text { UV type and experimental } \\
\text { conditions }\end{array}$ & Metabolites & Response & References \\
\hline $\begin{array}{l}\text { Apple (Malus } \\
\text { domestica) cv. } \\
\text { Braeburn }^{\mathrm{a}} / \text { Granny } \\
\text { Smith }^{\mathrm{b}}\end{array}$ & Skin & $\begin{array}{l}\text { Post-harvest UV-B } \\
97.0 \mathrm{~kJ} \mathrm{~m}^{-2} \\
2.5 \mathrm{~h}\end{array}$ & Quercetin-3-O-glycoside & $\begin{array}{l}a / b \\
+n\end{array}$ & $\begin{array}{l}\text { Solovchenko and } \\
\text { Schmitz-Eiberger, } 2003\end{array}$ \\
\hline $\begin{array}{l}\text { Blueberry (Vaccinium } \\
\text { corymbosum) cv. } \\
\text { Duke }\end{array}$ & $\begin{array}{l}\text { Complete } \\
\text { fruit }\end{array}$ & $\begin{array}{l}\text { Post-harvest UV-C } \\
4.3 \mathrm{~kJ} \mathrm{~m}^{-2} \\
24 \mathrm{~h}^{\text {(highdose) }}\end{array}$ & $\begin{array}{l}\text { Myricetin-3-O-arabinoside } \\
\text { Quercetin-3-O-galactoside } \\
\text { Quercetin-3-O-glucoside } \\
\text { Kaempferol-3-O-glucoside } \\
\text { Kaempferol-3-O-glucuronide } \\
\text { Delphinidin-3-O-galactoside } \\
\text { Dephinidin-3-O-arabinoside } \\
\text { Cyanidin-3-galactoside } \\
\text { Petunidin-3-O-galactoside } \\
\text { Petunidin-3-O-glucoside } \\
\text { Petunidin-3-arabinoside } \\
\text { Malvidin-3-O-galactoside } \\
\text { Malvidin-3-O-arabinoside }\end{array}$ & $\begin{array}{l}- \\
- \\
- \\
\mathrm{n} \\
- \\
- \\
- \\
\mathrm{n} \\
- \\
- \\
- \\
- \\
-\end{array}$ & Wang et al., 2009b \\
\hline $\begin{array}{l}\text { Grapevine (Vitis } \\
\text { vinifera) cv. Cabernet } \\
\text { Sauvignon }\end{array}$ & Skin & $\begin{array}{l}\text { Post-harvest } \\
\text { UV-A/B/C } \\
1.8 \mathrm{~kJ} \mathrm{~m}{ }^{-2} \\
\text { 3-week old berries* } \\
\text { 7-week* } \\
\text { 11-week* }\end{array}$ & $\begin{array}{l}\text { 2,3 -cis- flavan-3-ols } \\
\text { 2,3- trans-flavan-3-ols } \\
\text { (-)-epigallocatequin } \\
\text { [(-)-epigallocatequin-3-O-gallate } \\
+ \text { (-)-epicatequin + catechin] }\end{array}$ & $\begin{array}{l}+/-/+ \\
+/-/+ \\
+/-/+ \\
+/+/+ \\
\\
\mathrm{n} /+/+ \\
+/+/+ \\
+/+/+ \\
\mathrm{n} /+/+ \\
-/-/- \\
-/-/- \\
-/ \mathrm{n} /- \\
-/-/-\end{array}$ & Zhang et al., 2013 \\
\hline cv. Sauvignon blanc & Skin & $\begin{array}{l}\text { Solar UV-B } \\
6 \text { weeks post-veraison }\end{array}$ & $\begin{array}{l}\text { Quercetin-3-O-glucoside } \\
\text { Quercetin-3-O-glucuronide } \\
\text { Quercetin-3-O-rutinoside } \\
\text { Isorhamnetin-3-O-glucoside } \\
\text { Kaempferol-3-O-glucoside } \\
\text { Kaempferol-3-O-rutinoside } \\
\text { Kaempferol-3-O-glucuronide }\end{array}$ & $\begin{array}{l}+ \\
+ \\
+ \\
+ \\
+ \\
+ \\
+\end{array}$ & $\begin{array}{l}\text { Gregan et al., 2012; Liu } \\
\text { et al., } 2014\end{array}$ \\
\hline cv. Tempanillo & Skin & $\begin{array}{l}\text { Supplemental UV-B } \\
9.66 \mathrm{~kJ} \mathrm{~m}^{-2} \mathrm{~d}^{-1} \\
\text { set to ripness/onset of } \\
\text { veraison to ripness }\end{array}$ & $\begin{array}{l}\text { Kaempferol-3-O-galactoside } \\
\text { Kaempferol-3-O-glucoside } \\
\text { Quercetin-3-O-galactoside } \\
\text { Quercetin-3-O-glucuronide } \\
\text { Quercetin-3-O-glucoside } \\
\text { Isorhamnetin-3-O-glucoside } \\
\text { Syringetin-3-O-glucoside } \\
\text { Delphinidin-3-O-glucoside } \\
\text { Cyanidin-3-O-glucoside } \\
\text { Petunidin-3-O-glucoside }\end{array}$ & $\begin{array}{l}+/+ \\
+/+ \\
+/+ \\
+/+ \\
+/+ \\
\mathrm{n} / \mathrm{n} \\
\mathrm{n} / \mathrm{n} \\
\mathrm{n} / \mathrm{n} \\
\mathrm{n} / \mathrm{n} \\
+/ \mathrm{n}\end{array}$ & $\begin{array}{l}\text { Martínez-Lüscher et al., } \\
2014\end{array}$ \\
\hline
\end{tabular}




\begin{tabular}{|c|c|c|c|c|c|}
\hline & & & $\begin{array}{l}\text { Peonidin-3-O-glucoside } \\
\text { Malvidin-3-O-glucoside }\end{array}$ & $\begin{array}{l}+/ \mathrm{n} \\
\mathrm{n} / \mathrm{n}\end{array}$ & \\
\hline 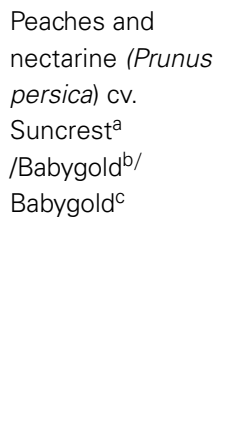 & Skin & $\begin{array}{l}\text { Post-harvest UV-B } \\
146 \mathrm{~kJ} \mathrm{~m}^{-2} \\
24 \mathrm{~h}\end{array}$ & $\begin{array}{l}\text { Quercetin-3-O-diglucoside } \\
\text { Quercetin-3-O-galactoside } \\
\text { Quercetin-3-O-rutinoside } \\
\text { Quercetin-3-O-glucoside } \\
\text { Kaempferol-3-O-galactoside } \\
\text { Kaempferol-3-O-rutinoside } \\
\text { Kaempferol-3-O-glucoside } \\
\text { Isorhamnetin-3-O-galactoside } \\
\text { Isorhamnetin-3-O-rutinoside } \\
\text { Isorhamnetin-3-O-glucoside } \\
\text { Cyanidin-3-O-glucoside }\end{array}$ & 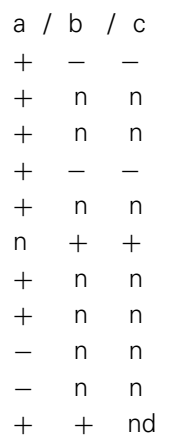 & Scattino et al., 2014 \\
\hline $\begin{array}{l}\text { Tomato (Solanum } \\
\text { lycopersicum) cv. } \\
\text { Money Make } / \text { hp-1 } \\
\text { mutant }^{\mathrm{b}}\end{array}$ & $\begin{array}{l}\text { Skin } \\
\text { Flesh }\end{array}$ & $\begin{array}{l}\text { Post-harvest UV-B } \\
6.08 \mathrm{~kJ} \mathrm{~m}^{-2} \mathrm{~d}^{-1} \\
\text { mature green fruit stage }\end{array}$ & $\begin{array}{l}\text { Naringenin } \\
\text { 3-quercetin-pentosyl-rutinoside } \\
\text { Rutin (quercetin 3-O-rutinoside) }\end{array}$ & $\begin{array}{ll}\mathrm{a} / \mathrm{b} \\
& \\
& \\
+ & + \\
+ & \mathrm{n} \\
+ & \mathrm{n} \\
\mathrm{nd} & \mathrm{nd} \\
\mathrm{n} & \mathrm{n} \\
\mathrm{n} & +\end{array}$ & Castagna et al., 2014 \\
\hline
\end{tabular}

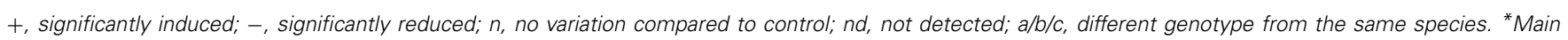
responses between hours (Zhang et al., 2013).

expression of $M d M Y B A$ and anthocyanin pathway genes in apple skin (Ban et al., 2007; Peng et al., 2013).

Martínez-Lüscher et al. (2014) exposed red grapevine variety (cv. Tempranillo) to two doses (5.98 and $9.66 \mathrm{~kJ} \mathrm{~m}^{-2} \mathrm{~d}^{-1}$ ) of supplemental UV-B radiation, under controlled conditions, in order to study the effect on grape traits including flavonoid profile. The contents of anthocyanins and flavonols were enhanced by UV-B in grape berry skin, and qualitative differences were also detected in the flavonol profiles compared to untreated fruits (Martínez-Lüscher et al., 2014; Table 2). In Cabernet Sauvignon grapevine variety, the accumulation of flavan-3-ols was found to be developmental stage-dependent in response to the three types of supplemental UV-light (Zhang et al., 2013). Supplemental UVA irradiation promoted flavan-3-ol accumulation and transcript levels of related genes at all studied early developmental stages (311 weeks after flowering), whereas UV-B and UV-C were effective only grape berries of 7-11 weeks after flowering. The results indicated that UV radiation increased flavan-3-ol levels during the berry development but did not increase the flavan-3-ol content in the mature berries (Zhang et al., 2013).

Significant post-harvest effects of UV-B exposure on flavonoid biosynthesis has been reported in different nectarine varieties. The accumulation of anthocyanins in the skin of nectarines (cv. Stark Red Gold) exposed to white light supplemented with UV-light was after $72 \mathrm{~h}$ in accordance with enhanced transcript levels of flavonoid pathway genes such as PpDFR and PpUFGT (Ravaglia et al., 2013). Particularly, the PpMYB10 gene was strongly responsive to the treatment but the levels of PAs and flavonols were not changed during the experiment. However, increment in the transcript level of PpFLS1 was reported, which suggests the accumulation of flavonols in a longer period than $72 \mathrm{~h}$ (Ravaglia et al., 2013). In apple, the exposure of post-harvest fruits to visible light supplemented with UV-B also increased the content of total flavonoids, and in particular quercetinglycosides and anthocyanins, in shade-grown fruits of cultivar Aroma (Hagen et al., 2007). Another post-harvest treatment with UV-B/visible light showed similar results in European pear ( $P$. communis) and Chinese sand pear (P. pyrifolia Nakai, Qian et al., 2013; Sun et al., 2014). The UV-B radiation also increased significantly flavonoid levels, especially flavonols, in the flesh of post-harvest tomato fruits at green mature stage (Castagna et al., 2014), whereas UV-A caused significant short term increment in anthocyanin content in tomato fruits at green mature stage (Guo and Wang, 2010).

Genotype-related differences were detected in a study focusing also on post-harvest effects of UV-B irradiation, in which fruits of cv. Suncrest and cv. Babygold 7 of peach and cv. Big Top of nectarine were irradiated with UV-B. Fruits of cultivars Big Top and cv. Suncrest responded by increasing the levels of flavonol and anthocyanidin glycosides whereas in cv. Babygold 7 that is lacking anthocyanins, flavonol levels decreased after UV-B irradiation (Table 2). The transcript levels of the structural phenylpropanoid and flavonoid pathway genes $\left(P_{p} C 4 H\right.$, Pp4CL, PpF3H, PpDFR, PpCHI, PpPAL, PpCHS, PpLDOX) were consistent with the detected metabolite levels (Scattino et al., 2014).

The post-harvest treatments with UV-C light have been reported to delay fruit senescence and increase the antioxidant activity and flavonoid content in fruits. Wang et al. (2009b) tested the effect of UV-C dosages from 0.43 to $6.45 \mathrm{~kJ} \mathrm{~m}^{-2}$ (1-15 min 


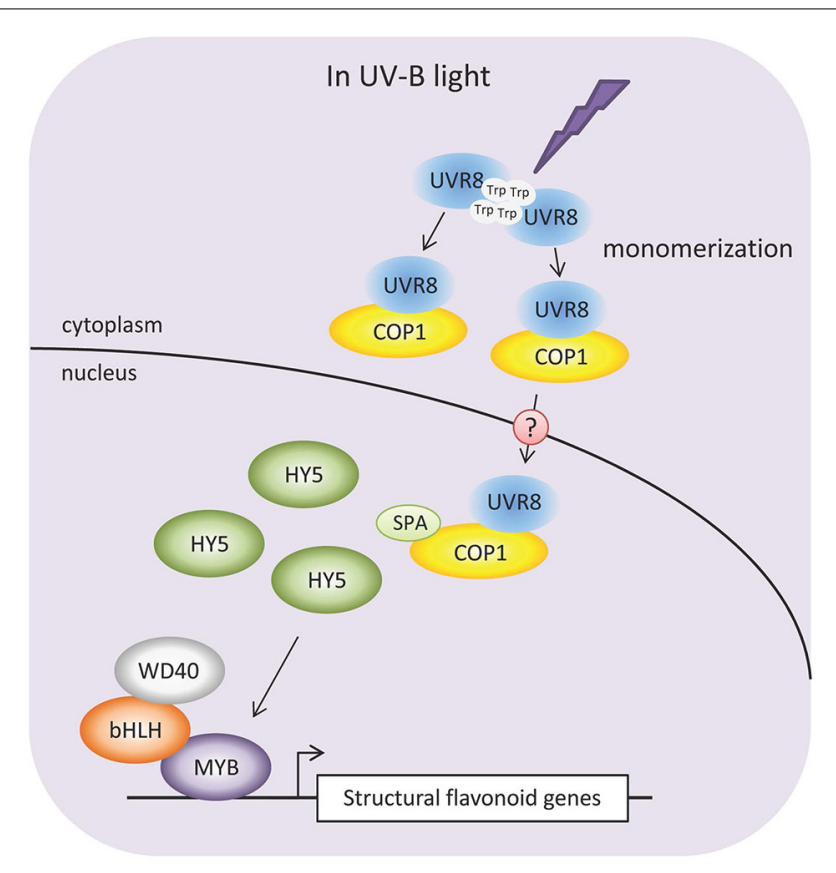

FIGURE 4 | Proposed mechanism for signaling pathway affecting flavonoid biosynthesis under UV-B radiation. UV-B radiation is strongly absorbed by tryptophan (Trp) amino acid residues in the dimeric form of UVR8 photoreceptor leading to the monomerization of UVR8. Monomeric UVR8 and COP1 form a complex that accumulates in the nucleus of the cells. The UVR8-COP1-SPA complex stabilizes bZIP transcription factor HY5 promoting the activity of different R2R3 MYBs for the transcription of specific flavonoid biosynthesis genes (Favory et al., 2009; Christie et al., 2012; Jenkins, 2014; Li et al., 2014). treatments) on flavonoid contents and antioxidant activity in post-harvest blueberries ( $V$. corymbosum). The results indicated substantial increase in flavonol and anthocyanidin glycosides and antioxidant activities instantly after the treatments. However, the contents decreased to the same level with the untreated control berries after $19 \mathrm{~h}$ from the treatments. In strawberry, the effect of $4.1 \mathrm{~kJ} \mathrm{~m}^{-2} \mathrm{UV}-\mathrm{C}$ radiation on anthocyanin content, antioxidant activity, and overall quality was studied in post-harvest berries at the large green maturity stage (Li et al., 2014). UV$\mathrm{C}$ induced accumulation of anthocyanins and flavonols as well as activity of the enzymes of the phenylpropanoid pathway, but after 3 days under UV-C light these effects were not detected anymore. UV-C irradiation also positively enhanced the content of stilbene cis- and trans-piceid together with quercetin-3-Ogalactoside and quercetin-3-O-glucoside in grape berry skin up to 3 -fold respect to control grape berries (Crupi et al., 2013). UV-C irradiation has also been shown to increase the radical scavenging properties of papaya fruit skin due enhanced flavonoid content (Rivera-Pastrana et al., 2013).

\section{PHOTOPERIOD}

Photoperiod influences various ways in the growth and development of plants. The photoperiodic conditions can also affect the biosynthesis of secondary metabolites. For instance, the biosynthesis of anthocyanins in Xanthium flowers has been shown to be under photoperiodic regulation (Taylor, 1965). Plants possess an internal timekeeping system, circadian clock, which runs on a period of about $24 \mathrm{~h}$. In addition to light perception, circadian clock activity is essential for the detection of photoperiod and subsequent mediation of responses to daily changes in light conditions. Light signaling pathways and circadian clock are interconnected as photoreceptors are involved in entrainment of the clock and the circadian clock in the regulation of the photoreceptor genes (Harmer, 2009; Lopez et al., 2012).

Increased levels of flavonoids, especially anthocyanins under longer photoperiod have been detected in different plant species (Camm et al., 1993; Reyes et al., 2004; Carvalho et al., 2010; reviewed by Jaakola and Hohtola, 2010) but opposite results have also been reported (Steindal et al., 2013). Studies focusing purely on the effect of circadian rhythms on the flavonoid content in fruits are scarce and the results are often difficult to analyze because of many variables. In field studies, along with day length and total irradiation level, diurnal temperature changes also affect the flavonoid biosynthesis. In controlled experiment with bilberry, $24 \mathrm{~h}$ day length yielded significantly higher levels of anthocyanins in fruits compared with $12 \mathrm{~h}$ day length treatment (Uleberg et al., 2012). Field experiments have also shown higher anthocyanin levels in Vaccinium berries growing under longer day length in the northern latitudes (Lätti et al., 2008, 2010; Akerström et al., 2010). Long-term field experiments with currants (Ribes spp.) showed contradictory results in the flavonoid levels between different latitudes (Zheng et al., 2012; Yang et al., 2013). The content of flavonols in red, white and green currants and anthocyanins in red currant cultivars were notably higher in the northern growth habitants whereas opposite was detected in black currant ( $R$. nigrum) cultivars. However, these field experiments were performed in long day conditions with the differences in day length varying from about $16 \mathrm{~h}$ to $24 \mathrm{~h}$ during the growth period.

Increasing evidence has been gathered to support the idea that ubiquitination-mediated targeted protein degradation is involved in controlling day length perception in plants in response to photoperiod. Ubiquitin-mediated protein degradation by COP1 has been shown to be important element in stabilization of circadian clock components in Arabidopsis (Lau and Deng, 2012; Piñeiro and Jarillo, 2013).

\section{CONCLUDING REMARKS}

In conclusion, flavonoid composition in fruits is strongly affected by surrounding light conditions. In general, higher solar radiation tends to increase flavonoid content in fruits. Specific wavelengths can also alter the profile of flavonoids in fruit tissues. However, variation in response can be high between and even within species. Interaction of specific light conditions with other environmental factors can also change the response markedly. Although biosynthesis of flavonoids has been extensively studied, only recently the underlying molecular mechanisms of lightcontrolled flavonoid biosynthesis have begun to be revealed. Some of the mechanisms shown in model plants, such as COP1mediated signaling pathways, have recently also been found in fruit tissues. Understanding the regulation of flavonoid biosynthetic pathway as well as involved light signaling machinery in 
fruit producing species is important to generate and select fruits enriched with flavonoid compounds to obtain desirable dietary and health-beneficial properties. The same compounds can also affect to self-life of the fruits. Moreover, several recent studies show that pre- and post-harvest treatments with selected light conditions have potential for commercial applications.

\section{ACKNOWLEDGMENTS}

Laura Zoratti acknowledges the Department of Applied Rosaceous Genomics of Fondazione Edmund Mach (Italy) for having made available the instruments for measuring sunlight spectra in Italy's area.

\section{REFERENCES}

Akagi, T., Katayama-Ikegami, A., Kobayashi, S., Sato, A., Kono, A., and Yonemori, K. (2012). Seasonal abscisic acid signal and a basic leucine zipper transcription factor, DkbZIP5, regulate proanthocyanidin biosynthesis in persimmon fruit. Plant Physiol. 158, 1089-1102. doi: 10.1104/pp.111.191205

Åkerström, A., Jaakola, L., Bång, U., and Jäderlund, A. (2010). Effects of latitude-related factors and geographical origin on anthocyanidin concentrations in fruits of Vaccinium myrtillus L. (bilberries). J. Agric. Food Chem. 58, 11939-11945. doi: 10.1021/jf102407n

Allan, A. C., Hellens, R. P., and Laing, W. A. (2008). MYB transcription factors that colour our fruit. Trends Plant Sci. 13, 99-102. doi: 10.1016/j.tplants.2007.11.012

Allende, A., and Artés, F. (2003). UV-C radiation as a novel technique for keeping quality of fresh processed "Lollo Rosso" lettuce. Food Res. Int. 36, 739-746. doi: 10.1016/S0963-9969(03)00054-1

Andrady, A., Aucamp, P. J., Bais, A. F., Ballaré, C. L., Björn, L., Bornman, J. F., et al. (2010). Environmental effects of ozone depletion and its interactions with climate change: progress report, 2009. Photochem. Photobiol. Sci. 9, 275-294. doi: $10.1039 / \mathrm{b} 923342 \mathrm{n}$

Anttonen, M. J., Hoppula, K. I., Nestby, R., Verheul, M. J., and Karjalainen, R. O. (2006). Influence of fertilization, mulch color, early forcing, fruit order, planting date, shading, growing environment, and genotype on the contents of selected phenolics in strawberry (Fragaria $\times$ ananassa Duch.) fruits. J. Agric. Food Chem. 54, 2614-2620. doi: 10.1021/jf052947w

Arakawa, O. (1993). Effect of ultraviolet light on anthocyanin synthesis in lightcolored sweet cherry, cv. Sato Nishiki. J. Jpn. Soc. Hortic. Sci. 62, 543-546. doi: $10.2503 /$ jjshs.62.543

Arakawa, O., Hori, Y., and Ogata, R. (1985). Relative effectiveness and interaction of ultraviolet-B, red and blue light in anthocyanin synthesis of apple fruit. Physiol. Plant. 64, 323-327. doi: 10.1111/j.1399-3054.1985.tb03347.x

Azari, R., Tadmor, Y., Meir, A., Reuveni, M., Evenor, D., Nahon, S., et al. (2010). Light signaling genes and their manipulation towards modulation of phytonutrient content in tomato fruits. Biotechol. Adv. 28, 108-118. doi: 10.1016/j.biotechadv.2009.10.003

Azuma, A., Yakushiji, H., Koshita, Y., and Kobayashi, S. (2012). Flavonoid biosynthesis-related genes in grape skin are differentially regulated by temperature and light conditions. Planta 236, 1067-1080. doi: 10.1007/s00425-0121650-x

Ballaré, C. L. (2014). Light regulation of plant defence. Ann. Rev. Plant Biol. 65, 335-363. doi: 10.1146/annurev-arplant-050213-040145

Ban, Y., Honda, C., Hatsuyama, Y., Igarashi, M., Bessho, H., and Moriguchi, T. (2007). Isolation and functional analysis of a MYB transcription factor gene that is a key regulator for the development of red coloration in apple skin. Plant Cell Physiol. 48, 958-970. doi: 10.1093/pcp/pcm066

Bogs, J., Jaffé, F. W., Takos, A. M., Walker, A. R., and Robinson, S. P. (2007). The grapevine transcription factor VvMYBPA1 regulates proanthocyanidin synthesis during fruit development. Plant Physiol. 143, 1347-1361. doi: 10.1104/pp.106.093203

Briggs, W. R., and Christie, J. C. (2002). Phototropins 1 and 2: versatile plant blue-light receptors. Trends Plant Sci. 7, 204-210. doi: 10.1016/S13601385(02)02245-8

Brown, B. A., Cloix, C., Jiang, G., Kaiserli, E., Herzyk, P., Kliebenstein, D. J., et al. (2005). A UV-B-specific signaling component orchestrates plant UV protection.
Proc. Natl. Acad. Sci. U.S.A. 102, 18225-18230. doi: 10.1073/pnas.0507 187102

Camm, E. L., McCallum, J., Leaf, E., and Koupai-Abyazani, M. R. (1993). Cold-induced purpling of Pinus contorta seedlings depends on previous daylength treatment. Plant Cell Environ. 16, 761-764. doi: 10.1111/j.13653040.1993.tb00497.x

Carbone, F., Preuss, A., De Vos, R. C. H., D’Amico, E., Perrotta, G., Bovy, A., et al. (2009). Developmental, genetic and environmental factors affect the expression of flavonoid genes, enzymes and metabolites in strawberry fruits. Plant Cell Environ. 32, 1117-1131. doi: 10.1111/j.1365-3040.2009.01994.x

Carvalho, I. S., Cavaco, T., Carvalho, L. M., and Duque, P. (2010). Effect of photoperiod on flavonoid pathway activity in sweet potato (Ipomoea batatas (L.) Lam.) leaves. Food Chem. 118, 384-390. doi: 10.1016/j.foodchem.2009.05.005

Carvalho, R. F., Takaki, M., and Azevedo, R. A. (2011). Plant pigments: the many faces of light perception. Acta Physiol. Plant. 33, 241-248. doi: 10.1007/s11738010-0533-7

Casal, J. J. (2013). Photoreceptor signaling networks in plant responses to shade. Annu. Rev. Plant Biol. 64, 403-427. doi: 10.1146/annurev-arplant-050312120221

Castagna, A., Dall'Asta, C., Chiavaro, E., Galaverna, G., and Ranieri, A. (2014). Effect of post-harvest UV-B irradiation on polyphenol profile and antioxidant activity in flesh and peel tomato fruits. Food Bioprocess Technol. 7, 2241-2250. doi: 10.1007/s11947-013-1214-5

Chen, C., Xiao, Y. G., Li, X., and Ni, M. (2012). Light-regulated stomatal aperture in Arabidopsis. Mol. Plant 5, 566-572. doi: 10.1093/mp/sss039

Christie, J. M., Arvai, A. S., Baxter, K. J., Heilmann, M., Pratt, A. J., O’Hara A., et al. (2012). Plant UVR8 photoreceptor senses UV-B by tryptophanmediated disruption of cross-dimer salt bridges. Science 335, 1492-1496. doi: $10.1126 /$ science. 1218091

Cockell, C. S., and Knowland, J. (1999). Ultraviolet radiation screening compounds. Biol. Rev. Camb. Philos. Soc. 74, 311-345. doi: 10.1111/j.1469185X.1999.tb00189.x

Cominelli, E., Gusmaroli, G., Allegra, D., Galbiati, M., Wade, H. K., Jenkins, G. I., et al. (2008). Expression analysis of anthocyanin regulatory genes in response to different light qualities in Arabidopsis thaliana. J. Plant Physiol. 165, 886-894. doi: 10.1016/j.jplph.2007.06.010

Cortell, J. M., and Kennedy, J. A. (2006). Effect of shading on accumulation of flavonoid compounds in (Vitis vinifera L.) pinot noir fruit and extraction in a model system. J. Agric. Food Chem. 54, 8510-8520. doi: 10.1021/jf0616560

Crupi, P., Pichierri, A., Basile, T., and Antonacci, D. (2013). Postharvest stilbenes and flavonoids enrichment of table grape cv Redglobe (Vitis vinifera L.) as affected by interactive UV-C exposure and storage conditions. Food Chem. 141, 802-808. doi: 10.1016/j.foodchem.2013.03.055

Czemmel, S., Heppel, S. C., and Bogs, J. (2012). R2R3 MYB transcription factors: key regulators of the flavonoid biosynthetic pathway in grapevine. Protoplasma 249, S109-S118. doi: 10.1007/s00709-012-0380-Z

Czemmel, S., Stracke, R., Weisshaar, B., Cordon, N., Harris, N. N., Walker, A. R., et al. (2009). The grapevine R2R3-MYB transcription factor VvMYBF1 regulates flavonol synthesis in developing grape berries. Plant Physiol. 151, 1513-1530. doi: 10.1104/pp.109.142059

Davuluri, G. R., van Tuinen, A., Fraser, P. D., Manfredonia, A., Newman, R. Burgess, D., et al. (2005). Fruit-specific RNAi-mediated suppression of DET1 enhances carotenoid and flavonoid content in tomatoes. Nat. Biotechnol. 23, 890-895. doi: 10.1038/nbt1108

Downey, M. O., Harvey, J. S., and Robinson, S. P. (2004). The effect of bunch shading on berry development and flavonoid accumulation in Shiraz grapes. Aust. J. Grape Wine Res. 10, 55-73. doi: 10.1111/j.1755-0238.2004.tb00008.x

Falcone Ferreyra, M. L., Rius, S. P., and Casati, P. (2012). Flavonoids: Biosynthesis, biological functions, and biotechnological applications. Front. Plant Sci. 3:222. doi: 10.3389/fpls.2012.00222

Farman, J., Gardiner, B., and Shanklin, J. (1985). Large losses of total ozone in Antarctica reveal seasonal ClOx/NOx interaction. Nature 315, 207-210. doi: $10.1038 / 315207 \mathrm{a} 0$

Favory, J. J., Stec, A., Gruber, H., Rizzini, L., Oravecz, A., Funk, M., et al. (2009). Interaction of COP1 and UVR8 regulates UV-B-induced photomorphogenesis and stress acclimation in Arabidopsis. EMBO J. 28, 591-601. doi: 10.1038/emboj.2009.4

Feldbrügge, M., Sprenger, M., Hahlbrock, K., and Weisshaar, B. (1997). PcMYB1, a novel plant protein containing a DNA-binding domain with one MYB repeat, 
interacts in vivo with a light-regulatory promoter unit. Plant J. 11, 1079-1093. doi: 10.1046/j.1365-313X.1997.11051079.x

Feng, F., Li, M., Ma, F., and Cheng, L. (2013). Phenylpropanoid metabolites and expression of key genes involved in anthocyanin biosynthesis in the shaded peel of apple fruit in response to sun exposure. Plant Physiol. Biochem. 69, 54-61. doi: 10.1016/j.plaphy.2013.04.020

Feng, S., Wang, Y., Yang, S., Xu, Y., and Chen, X. (2010). Anthocyanin biosynthesis in pears is regulated by a R2R3-MYB transcription factor PyMYB10. Planta 232, 245-255. doi: 10.1007/s00425-010-1170-5

Frohnmeyer, H., and Staiger, D. (2003). Ultraviolet-B radiation-mediated responses in plants. Balancing damage and protection. Plant Physiol. 133, 1420-1428. doi: 10.1104/pp.103.030049

Fujita, A., Goto-Yamamoto, N., Aramaki, I., and Hashizume, K. (2006). Organspecific transcription of putative flavonol synthase genes of grapevine and effects of plant hormones and shading on flavonol biosynthesis in grape berry skins. Biosci. Biotechnol. Biochem. 70, 632-638. doi: 10.1271/bbb. 70.632

Gesell, A., Yoshida, K., Tran, L. T., and Constabel, C. P. (2014). Characterization of an apple TT2-type R2R3 MYB transcription factor functionally similar to the poplar proanthocyanidin regulator PtMYB134. Planta 240, 497-511. doi: 10.1007/s00425-014-2098-y

Giliberto, L., Perrotta, G., Pallara, P., Weller, J. L., Fraser, P. D., Bramley, P. M., et al. (2005). Manipulation of the blue light photoreceptor cryptochrome 2 in tomato affects vegetative development, flowering time, and fruit antioxidant content. Plant Physiol. 137, 199-208. doi: 10.1104/pp.104.051987

Giuntini, D., Lazzeri, V., Calvenzani, V., Dall'Asta, C., Galaverna, G., Tonelli, C., et al. (2008). Flavonoid profiling and biosynthetic gene expression in flesh and peel of two tomato genotypes grown under UV-B-depleted conditions during ripening. J. Agric. Food Chem. 56, 5905-5915. doi: 10.1021/jf80 03338

Gregan, S. M., Wargent, J. J., Liu, L., Shinkle, J., Hofmann, R., Winefield, C., et al. (2012). Effects of solar ultraviolet radiation and canopy manipulation on the biochemical composition of Sauvignon Blanc grapes. Aust. J. Grape Wine Res. 18, 227-238. doi: 10.1111/j.1755-0238.2012.00192.x

Guo, J., and Wang, M. (2010). Ultraviolet A-specific induction of anthocyanin biosynthesis and PAL expression in tomato (Solanum lycopersicum L.). Plant Growth Regul. 62, 1-8. doi: 10.1007/s10725-010-9472-y

Hagen, S. F., Borge, G. I. A., Bengtsson, G. B., Bilger, W., Berge, A., Haffner, K., et al. (2007). Phenolic contents and other health and sensory related properties of apple fruit (Malus domestica Borkh., cv. Aroma): effect of postharvest UV-B irradiation. Postharvest Biol. Tec. 45, 1-10. doi 10.1016/j.postharvbio.2007.02.002

Hardtke, C. S., Gohda, K., Osterlund, M. T., Oyama, T., Okada, K., and Deng, X. W. (2000). HY5 stability and activity in Arabidopsis is regulated by phosphorylation in its COP1 binding domain. EMBO J. 19, 4997-5006. doi: 10.1093/emboj/19.18.4997

Harmer, S. L. (2009). The circadian system in higher plants. Ann. Rev. Plant Biol. 60, 357-377. doi: 10.1146/annurev.arplant.043008.092054

Hartmann, U., Sagasser, M., Mehrtens, F., Stracke, R., and Weisshaar, B. (2005). Differential combinatorial interactions of cis-acting elements recognized by R2R3-MYB, BZIP, and BHLH factors control light-responsive and tissuespecific activation of phenylpropanoid biosynthesis genes. Plant Mol. Biol. 57, 155-171. doi: 10.1007/s11103-004-6910-0

He, J., and Giusti, M. (2010). Anthocyanins: natural colorants with healthpromoting properties. Annu. Rev. Food Sci. Technol. 1, 163-187. doi: 10.1146/annurev.food.080708.100754

Heijde, M., and Ulm, R. (2012). UV-B photoreceptor-mediated signaling in plants. Trends Plant Sci. 17, 230-237. doi: 10.1016/j.tplants.2012.01.007

Hichri, I., Barrieu, F., Bogs, J., Kappel, C., Delrot, S., and Lauvergeat, V. (2011). Recent advances in the transcriptional regulation of the flavonoid biosynthetic pathway. J. Exp. Bot. 62, 2465-2483. doi: 10.1093/jxb/erq442

Hollósy, F. (2002). Effects of ultraviolet radiation on plant cells. Micron 33, 179-197. doi: 10.1016/S0968-4328(01)00011-7

Huovinen, P., Gomez, I., and Lovengreen, C. (2006). A five-year study of solar ultraviolet radiation in Southern Chile $\left(39^{\circ} \mathrm{S}\right)$ : potential impact on physiology of coastal marine algae? Photochem. Photobiol. 82, 515-522. doi: 10.1562/2005-0705-RA-601

Jaakola, L. (2013). New insights into the regulation of anthocyanin biosynthesis in fruits. Trends Plant Sci. 18, 477-483. doi: 10.1016/j.tplants.2013.06.003
Jaakola, L., and Hohtola, A. (2010). Effect of latitude on flavonoid biosynthesis in plants. Plant Cell Environ. 33, 1239-1247. doi: 10.1111/j.13653040.2010.02154.x

Jaakola, L., Määttä, K., Pirttilä, A. M., Törrönen, R., Kärenlampi, S., and Hohtola, A. (2002). Expression of structural genes involved in anthocyanin biosynthesis in relation to anthocyanin and flavonoid levels during bilberry (Vaccinium myrtillus L.) fruit development. Plant Physiol. 130, 729-739. doi: 10.1104/pp. 006957

Jaakola, L., Määttä-Riihinen, K., Kärenlampi, S., and Hohtola, A. (2004). Activation of flavonoid biosynthesis by solar radiation in bilberry (Vaccinium myrtillus L.) leaves. Planta 218, 721-728. doi: 10.1007/s00425-003-1161-x

Jaakola, L., Poole, M., Jones, M. O., Kämäräinen-Karppinen, T., Koskimäki, J. J., Hohtola, A., et al. (2010). A SQUAMOSA MADS box gene involved in the regulation of anthocyanin accumulation in bilberry fruits. Plant Physiol. 153, 1619-1629. doi: 10.1104/pp.110.158279

Jaillon, O., Aury, J. M., Noel, B., Policriti, A., Clepet, C., Casagrande, A., et al. (2007). The grapevine genome sequence suggests ancestral hexaploidization in major angiosperm phyla. Nature 449, 463-467. doi: 10.1038/nature06148

Jang, I. C., Henriques, R., Seo, H. S., Nagatani, A., and Chua, N. H. (2010). Arabidopsis phytochrome interacting factor proteins promote phytochrome B polyubiquitination by COP1 E3 ligase in the nucleus. Plant Cell 22, 2370-2383. doi: $10.1105 /$ tpc. 109.072520

Jansen, M. A. K., Gaba, V., and Greenberg, B. M. (1998). Higher plants and UVB radiation: Balancing damage, repair and acclimation. Trends Plant Sci. 3, 131-135. doi: 10.1016/S1360-1385(98)01215-1

Jenkins, G. I. (2014). The UV-B photoreceptor UVR8: From structure to physiology. Plant Cell 26, 21-37. doi: 10.1105/tpc.113.119446

Jeong, R. D., Chandra-Shekara, A. C., Barman, S. R., Navarre, D., Klessig, D. F., Kachroo, A., et al. (2010). Cryptochrome 2 and phototropin 2 regulate resistance protein-mediated viral defense by negatively regulating an E3 ubiquitin ligase. Proc. Natl. Acad. Sci. U.S.A. 107, 13538-13543. doi: 10.1073/pnas.1004529107

Jeong, S. T., Goto-Yamamoto, N., Kobayashi, S., and Esaka, M. (2004). Effects of plant hormones and shading on the accumulation of anthocyanins and the expression of anthocyanin biosynthetic genes in grape berry skins. Plant Sci. 167, 247-252. doi: 10.1016/j.plantsci.2004.03.021

Jia, H. F., Chai, Y. M., Li, C. L., Lu, D., Luo, J. J., Qin, L., et al. (2011). Abscisic acid plays an important role in the regulation of strawberry fruit ripening. Plant Physiol. 157, 188-199. doi: 10.1104/pp.111.177311

Jia, H. J., Araki, A., and Okamoto, G. (2005). Influence of fruit bagging on aroma volatiles and skin coloration of "Hakuho" peach (Prunus persica Batsch). Postharvest Biol. Tec. 35, 61-68. doi: 10.1016/j.postharvbio.2004.06.004

Kadomura-Ishikawa, Y., Miyawaki, K., Noji, S., and Takahashi, A. (2013). Phototropin 2 is involved in blue light-induced anthocyanin accumulation in Fragaria $\times$ ananassa fruits. J. Plant Res. 126, 847-857. doi: 10.1007/s10265-0130582-2

Kaiserli, E., and Jenkins, G. I. (2007). UV-B promotes rapid nuclear translocation of the Arabidopsis UV-B-specific signaling component UVR8 and activates its function in the nucleus. Plant Cell 19, 2662-2673. doi: 10.1105/tpc.107. 053330

Kakani, V. G., Reddy, K. R., Zhao, D., and Sailaja, K. (2003). Field crop responses to ultraviolet-B radiation: a review. Agri. Forest Meteorol. 120, 191-218. doi: 10.1016/j.agrformet.2003.08.015

Karpinski, S., Szechynska-Hebda, M., Wituszynska, W., and Burdiak, P. (2013). Light acclimation, retrograde signalling, cell death and immune defences in plants. Plant Cell Environ. 36, 736-744. doi: 10.1111/pce.12018

Karppinen, K., Hirvelä, E., Nevala, T., Sipari, N., Suokas, M., and Jaakola, L. (2013). Changes in the abscisic acid levels and related gene expression during fruit development and ripening in bilberry (Vaccinium myrtillus L.). Phytochemistry 95, 127-134. doi: 10.1016/j.phytochem.2013.06.023

Kataoka, I., Beppu, K., and Sugiyama, A. (2005). Involvement of UV rays in sweet cherry fruit coloration during maturation. Acta Hortic. 667, 461-466.

Kataoka, I., Beppu, K., Sugiyama, A., and Taira, T. (1996). Enhancement of coloration of "Satoh-ni-shiki" sweet cherry fruit by postharvest irradiation with ultraviolet radiation. Environ. Control Biol. 34, 313-319. doi: 10.2525/ecb1963.34.313

Kobayashi, S., Goto-Yamamoto, N., and Hirochika, H. (2004). Retrotransposoninduced mutations in grape skin color. Science 304:982. doi: 10.1126/science.1095011 
Koes, R., Verweij, W., and Quattrocchio, F. (2005). Flavonoids: a colorful model for the regulation and evolution of biochemical pathways. Trends Plant Sci. 10, 236-242. doi: 10.1016/j.tplants.2005.03.002

Kohchi, T., Mukougawa, K., Frankenberg, N., Masuda, M., Yokota, A., and Lagarias, J. C. (2001). The Arabidopsis HY2 gene encodes phytochromobilin synthase, a ferredoxin-dependent biliverdin reductase. Plant Cell 13, 425-436. doi: $10.1105 /$ tpc.13.2.425

Kondo, S., Tomiyama, H., Rodyoung, A., Okawa, K., Ohara, H., Sugaya, S., et al. (2014). Abscisic acid metabolism and anthocyanin synthesis in grape skin are affected by light emitting diode (LED) irradiation at night. J. Plant Physiol. 171, 823-829. doi: 10.1016/j.plph.2014.01.001

Koyama, K., Ikeda, H., Poudel, P. R., and Goto-Yamamoto, N. (2012). Light quality affects flavonoid biosynthesis in young berries of Cabernet Sauvignon grape. Phytochemistry 78, 54-64. doi: 10.1016/j.phytochem.2012.02.026

Lai, B., Li, X. J., Hu, B., Qin, Y. H., Huang, X. M., Wang, H. C., et al. (2014). LcMYB1 is a key determinant of differential anthocyanin accumulation among genotypes, tissues, developmental phases and ABA and light stimuli in Litchi chinensis. PLoS ONE 9:e86293. doi: 10.1371/journal.pone.0086293

Lai, Y., Li, H., and Yamagishi, M. (2013). A review of target gene specificity of flavonoid R2R3-MYB transcription factors and a discussion of factors contributing to the target gene selectivity. Front. Biol. 8, 577-598. doi: $10.1007 / \mathrm{s} 11515-013-1281-\mathrm{z}$

Lätti, A. K., Jaakola, L., Riihinen, K. R., and Kainulainen, P. S. (2010). Anthocyanin and flavonol variation in bog bilberry (Vaccinium uliginosum L.) in Finland. J. Agric. Food Chem. 58, 427-433. doi: 10.1021/jf903033m

Lätti, A. K., Riihinen, K. R., and Kainulainen, P. S. (2008). Analysis of anthocyanin variation in wild populations of bilberry (Vaccinium myrtillus L.) in Finland. J. Agric. Food Chem. 56, 190-196. doi: 10.1021/jf072857m

Lau, O. S., and Deng, X. W. (2012). The photomorphogenic repressor COP1 and DET1: 20 years later. Trends Plant Sci. 17, 584-593. doi: 10.1016/j.tplants.2012.05.004

Lee, J., He, K., Stolc, V., Lee, H., Figueroa, P., Gao, Y., et al. (2007). Analysis of transcription factor HY5 genomic binding sites revealed its hierarchical role in light regulation of development. Plant Cell 19, 731-749. doi: 10.1105/tpc.106. 047688

Li, D., Luo, Z., Mou, W., Wang, Y., Ying, T., and Mao, L. (2014). ABA and UV-C effects on quality, antioxidant capacity and anthocyanin contents of strawberry fruit (Fragaria ananassa Duch.). Postharvest Biol. Tec. 90, 56-62. doi: 10.1016/j.postharvbio.2013.12.006

Li, J., Li, G., Gao, S., Martinez, C., He, G., Zhou, Z., et al. (2010). Arabidopsi transcription factor ELONGATED HYPOCOTYL5 plays a role in the feedback regulation of phytochrome a signaling. Plant Cell 22, 3634-3649. doi: $10.1105 /$ tpc. 110.075788

Li, P., Ma, F., and Cheng, L. (2013). Primary and secondary metabolism in the sunexposed peel and the shaded peel of apple fruit. Physiol. Plant. 148, 9-24. doi: 10.1111/j.1399-3054.2012.01692.x

Li, S. (2014). Transcriptional control of flavonoid biosynthesis: Fine-tuning of the MYB-bHLH-WD40 (MBW) complex. Plant Signal. Behav. 9:e27522. doi: $10.4161 /$ psb. 27522

Li, Y. Y., Mao, K., Zhao, C., Zhao, X. Y., Zhang, H. L., Shu, H. R., et al. (2012). MdCOP1 ubiquitin E3 ligases interact with MdMYB1 to regulate light-induced anthocyanin biosynthesis and red fruit coloration in apple. Plant Physiol. 160, 1011-1022. doi: 10.1104/pp.112.199703

Lin-Wang, K., Bolitho, K., Grafton, K., Kortstee, A., Karunairetnam, S., McGhie, T. K., et al. (2010). An R2R3 MYB transcription factor associated with regulation of the anthocyanin biosynthetic pathway in Rosaceae. BMC Plant Biol. 10:50. doi: 10.1186/1471-2229-10-50

Liu, H., Liu, B., Zhao, C., Pepper, M., and Lin, C. (2011). The action mechanisms of plant cryptochromes. Trends Plant Sci. 16, 684-691. doi: 10.1016/j.tplants.2011.09.002

Liu, L., Gregan, S., Winefield, C., and Jordan, B. (2014). From UVR8 to flavonol synthase: UV-B-induced gene expression in Sauvignon blanc grape berry. Plant Cell Environ. doi: 10.1111/pce.12349. [Epub ahead of print].

Lopez, L., Carbone, F., Bianco, L., Giuliano, G., Facella, P., and Perrotta, G. (2012). Tomato plants overexpressing cryptochrome 2 reveal altered expression of energy and stress-related gene products in response to diurnal cues. Plant Cell Environ. 35, 994-1012. doi: 10.1111/j.1365-3040.2011.02467.x

Løvdal, T., Olsen, K. M., Slimestad, R., Verheul, M., and Lillo, C. (2010). Synergetic effects of nitrogen depletion, temperature, and light on the content of phenolic compounds and gene expression in leaves of tomato. Phytochemistry 71, 605-613. doi: 10.1016/j.phytochem.2009.12.014

Maier, A., Schrader, A., Kokkelink, L., Falke, C., Welter, B., Iniesto, E., et al. (2013). Light and the E3 ubiquitin ligase COP1/SPA control the protein stability of the MYB transcription factors PAP1 and PAP2 involved in anthocyanin accumulation in Arabidopsis. Plant J. 74, 638-651. doi: 10.1111/tpj.12153

Martens, S., Preuss, A., and Matern, U. (2010). Multifunctional flavonoid dioxygenases: Flavonol and anthocyanin biosynthesis in Arabidopsis thaliana L. Phytochemistry 71, 1040-1049. doi: 10.1016/j.phytochem.2010.04.016

Martínez-Lüscher, J., Torres, N., Hilbert, G., Richard, T., Sánchez-Díaz, M., Delrot, $\mathrm{S}$., et al. (2014). Ultraviolet-B radiation modifies the quantitative and qualitative profile of flavonoids and amino acids in grape berries. Phytochemistry 102, 106-114. doi: 10.1016/j.phytochem.2014.03.014

Matus, J. T., Loyola, R., Vega, A., Peña-Neira, A., Bordeu, E., Arce-Johnson, P., et al. (2009). Post-veraison sunlight exposure induces MYB-mediated transcriptional regulation of anthocyanin and flavonol synthesis in berry skins of Vitis vinifera. J. Exp. Bot. 60, 853-867. doi: 10.1093/jxb/ern336

Matus, J. T., Poupin, M. J., Cañón, P., Bordeu, E., Alcalde, J. A., and Arce-Johnson, P. (2010). Isolation of WDR and bHLH genes related to flavonoid synthesis in grapevine (Vitis vinifera L.). Plant Mol. Biol. 72, 607-620. doi: 10.1007/s11103010-9597-4

McKenzie, R., Bodeker, G., Scott, G., Slusser, J., and Lanz, K. (2006). Geographical differences in erythemally-weighted UV measured at mid-latitude USDA sites. Photochem. Photobiol. Sci. 5, 343-352. doi: 10.1039/B510943D

Miyawaki, K., Fukuoka, S., Kadomura, Y., Hamaoka, H., Mito, T., Ohuchi, H., et al. (2012). Establishment of a novel system to elucidate the mechanisms underlying light-induced ripening of strawberry fruit with Agrobacterium-mediated RNAi technique. Plant Biotechnol. 29, 271-277. doi: 10.5511/plantbiotechnology.12.0406a

Möglich, A., Yang, X., Ayers, R. A., and Moffat, K. (2010). Structure and function of plant photoreceptors. Annu. Rev. Plant Biol. 61, 21-47. doi: 10.1146/annurevarplant-042809-112259

Mpoloka, S. W. (2008). Effects of prolonged UV-B exposure in plants. Afr. J. Biotechnol. 7, 4874-4883. doi: 10.5897/AJB08.075

Murray, X. J., Holcroft, D. M., Cook, N. C., and Wand, S. J. E. (2005) Postharvest quality of "Laetitia" and "Songold" (Prunus salicina Lindell) plums as affected by preharvest shading treatments. Postharvest Biol. Tec. 37, 81-92. doi: 10.1016/j.postharvbio.2005.02.014

Niu, S. S., Xu, C. J., Zhang, W. S., Zhang, B., Li, X., Lin-Wang, K., et al. (2010). Coordinated regulation of anthocyanin biosynthesis in Chinese bayberry (Myrica rubra) fruit by a R2R3 MYB transcription factor. Planta 231, 887-899. doi: 10.1007/s00425-009-1095-z

Palapol, Y., Ketsa, S., Lin-Wang, K., Ferguson, I. B., and Allan, A. C. (2009). A MYB transcription factor regulates anthocyanin biosynthesis in mangosteen (Garcinia mangostana L.) fruit during ripening. Planta 229, 1323-1334. doi: 10.1007/s00425-009-0917-3

Peng, T., Saito, T., Honda, C., Ban, Y., Kondo, S., Liu, J. H., et al. (2013). Screening of UV-B-induced genes from apple peels by SSH: possible involvement of MdCOP1-mediated signaling cascade genes in anthocyanin accumulation. Physiol. Plant. 148, 432-444. doi: 10.1111/ppl.12002

Pereira, G. E., Gaudillere, J. P., Pieri, P., Hilbert, G., Maucourt, M., Deborde, C., et al. (2006). Microclimate influence on mineral and metabolic profiles of grape berries. J. Agric. Food Chem. 54, 6765-6775. doi: 10.1021/jf061013k

Petroni, K., and Tonelli, C. (2011). Recent advances on the regulation of anthocyanin synthesis in reproductive organs. Plant Sci. 181, 219-229. doi: 10.1016/j.plantsci.2011.05.009

Piñeiro, M., and Jarillo, J. A. (2013). Ubiquitination in the control of photoperiodic flowering. Plant Sci. 198, 98-109. doi: 10.1016/j.plantsci.2012.10.005

Qian, M., Zhang, D., Yue, X., Wang, S., Li, X., and Teng, Y. (2013). Analysis of different pigmentation patterns in "Mantianhong" (Pyrus pyrifolia Nakai) and "Cascade" (Pyrus communis L.) under bagging treatment and postharvest UV-B/visible irradiation conditions. Sci. Hortic. 151, 75-82. doi: 10.1016/j.scienta.2012.12.020

Ravaglia, D., Espley, R. V., Henry-Kirk, R. A., Andreotti, C., Ziosi, V., Hellens, R. P., et al. (2013). Transcriptional regulation of flavonoid biosynthesis in nectarine (Prunus persica) by a set of R2R3 MYB transcription factors. BMC Plant Biol. 13:68. doi: 10.1186/1471-2229-13-68

Reed, J. W. (1999). Phytochromes are Pr-ipatetic kinases. Curr. Opin. Plant Biol. 2, 393-397. doi: 10.1016/S1369-5266(99)00011-4 
Reyes, L. F., Miller, J. C., and Cisneros-Zevallos, L. (2004). Environmental conditions influence the content and yield of anthocyanins and total phenolics in purple- and red-flesh potatoes during tuber development. Am. J. Potato Res. 81, 187-193. doi: 10.1007/BF02871748

Rivera-Pastrana, D. M., Gardea, A. A., Yahia, E. M., Martìnez-Têllez, M. A., and Gonzàles-Aguilar, G. A. (2013). Effect of UV-C irradiation and low temperature storage on bioactive compounds, antioxidant enzymes and radical scavenging of papaya fruit. J. Food Sci. Technol. doi: 10.1007/s13197-013-0942-x

Rizzini, L., Favory, J. J., Cloix, C., Faggionato, D., O'Hara, A., Kaiserli, E., et al. (2011). Perception of UV-B by the Arabidopsis UVR8 protein. Science 332, 103-106. doi: 10.1126/science.1200660

Robertson, G. W. (1966). The light composition of solar and sky spectra available to plants. Ecology 47, 640-643. doi: 10.2307/1933945

Salvatierra, A., Pimentel, P., Moya-Leon, M. A., Caligari, P. D. S., and Herrera, R. (2010). Comparison of transcriptional profiles of flavonoid genes and anthocyanin contents during fruit development of two botanical forms of Fragaria chiloensis ssp. chiloensis. Phytochemistry 71, 1839-1847. doi: 10.1016/j.phytochem.2013.02.016

Scattino, C., Castagna, A., Neugart, S., Chan, H. M., Schreiner, M., Crisosto, C. H., et al. (2014). Post-harvest UV-B irradiation induces changes of phenol contents and corresponding biosynthetic gene expression in peaches and nectarines. Food Chem. 163, 51-60. doi: 10.1016/j.foodchem.2014.04.077

Shin, D. H., Choi, M., Kim, K., Bang, G., Cho, M., Choi, S. B., et al. (2013). HY5 regulates anthocyanin biosynthesis by inducing the transcriptional activation of the MYB75/PAP1 transcription factor in Arabidopsis. FEBS Lett. 587, 1543-1547. doi: 10.1016/j.febslet.2013.03.037

Shulaev, V., Sargent, D. J., Crowhurst, R. N., Mockler, T. C., Folkerts, O., Delcher, A. L., et al. (2011). The genome of woodland strawberry (Fragaria vesca). Nat. Genet. 43, 109-116. doi: 10.1038/ng.740

Smith, J. L., Burritt, D. J., and Bannister, P. (2000). Shoot dry weight, chlorophyll and UV-B-absorbing compounds as indicators of a plant's sensitivity to UV-B radiation. Ann. Bot. 86, 1057-1063. doi: 10.1006/anbo.2000.1270

Solovchenko, A., and Schmitz-Eiberger, M. (2003). Significance of skin flavonoids for UV-B-protection in apple fruits. J. Exp. Bot. 54, 1977-1984. doi $10.1093 /$ jxb/erg199

Spayd, S. E., Tarara, J. M., Mee, D. L., and Ferguson, J. C. (2002). Separation of sunlight and temperature effects on the composition of Vitis vinifera cv. Merlot berries. Am. J. Enol. Vitic. 53, 171-182.

Steindal, A. L. H., Mølmann, J., Bengtsson, G. B., and Johansen, T. J. (2013). Influence of day length and temperature on the content of health-related compounds in Broccoli (Brassica oleracea L. var. italica). J. Agric. Food Chem. 61, 10779-10786. doi: 10.1021/jf403466r

Stevens, C., Wilson, C. L., Lu, J. Y., Khan, V. A., Chalutz, E., Droby, S., et al. (1996). Plant hormesis induced by ultraviolet light-C for controlling postharvest diseases of tree fruits. Crop Prot. 15, 129-134. doi: 10.1016/0261-2194(95)00082-8

Stracke, R., Favory, J. J., Gruber, H., Bartelniewoehner, L., Bartels, S., Binkert, M., et al. (2010). The Arabidopsis bZIP transcription factor HY5 regulates expression of the PFG1/MYB12 gene in response to light and ultravioletB radiation. Plant Cell Environ. 33, 88-103. doi: 10.1111/j.1365-3040.2009. 02061.x

Sullivan, J. A., and Rozema, J. (1999). "UV-B efects on terrestrial plant growth and photosynthesis," in Stratospheric Ozone Depletion: The Effects of Enhanced UV-B Radiation on Terrestrial Ecosystems, ed J. Rozema (Leiden: Backhuys Publishers), 39-57.

Sun, Y., Qian, M., Wu, R., Niu, Q., Teng, Y., and Zhang, D. (2014). Postharvest pigmentation in red Chinese sand pears (Pyrus pyrifolia Nakai) in response to optimum light and temperature. Postharvest Biol. Tec. 91, 64-71. doi: 10.1016/j.postharvbio.2013.12.015

Takos, A. M., Jaffé, F. W., Jacob, S. R., Bogs, J., Robinson, S. P., and Walker, A. R. (2006a). Light-induced expression of a MYB gene regulates anthocyanin biosynthesis in red apples. Plant Physiol. 142, 1216-1232. doi: 10.1104/pp.106. 088104

Takos, A. M., Robinson, S. P., and Walker, A. R. (2006b). Transcriptional regulation of the flavonoid pathway in the skin of dark grown "Cripps" Red' apples in response to sunlight. J. Hortic. Sci. Biotechnol. 81, 735-744.

Taulavuori, K., Sarala, M., and Taulavuori, E. (2010). "Growth response of trees to arctic light environment," in Progress in Botany 71, eds U. Lüttdge, W. Beyschlag, B. Büdel, and D. Francis (Heidelberg: Springer-Verlag Berlin), 157-168.
Taylor, A. O. (1965). Some effects of photoperiod on the biosynthesis of phenylpropane derivates in Xanthium. Plant Physiol. 40, 273-280. doi: 10.1104/pp.40.2.273

Uleberg, E., Rohloff, J., Jaakola, L., Trôst, K., Junttila, O., Häggman, H., et al. (2012). Effects of temperature and photoperiod on yield and chemical composition of northern and southern clones of bilberry (Vaccinium myrtillus L.). J. Agric. Food Chem. 60, 10406-10414. doi: 10.1021/jf302924m

Velasco, R., Zharkikh, A., Affourtit, J., Dhinga, A., Cestaro, A., Kalyanaraman, A., et al. (2010). The genome of the domesticated apple (Malus $\mathrm{x}$ domestica Borkh.). Nat. Genet. 42, 833-839. doi: 10.1038/ng.654

Verde, I., Abbott, A. G., Scalabrin, S., Jung, S., Shu, S., Marroni, F., et al. (2013). The high-quality draft genome of peach (Prunus persica) identifies unique patterns of genetic diversity, domestication and genome evolution. Nat. Genet. 45 , 487-494. doi: 10.1038/ng.2586

Vierstra, R. D. (2009). The ubiquitin-26S proteasome system at the nexus of plant biology. Nat. Rev. Mol. Cell Biol. 10, 385-397. doi: 10.1038/nrm2688

Vimolmangkang, S., Zheng, D., Han, Y., Khan, M., Soria-Guerra, R., and Korban, S. S. (2014). Transcriptome analysis of the exocarp of apple fruit identifies light-induced genes involved in red color pigmentation. Gene 534, 78-87. doi: 10.1016/j.gene.2013.10.007

Wagner, J. R., Brunzelle, J. S., Forest, K. T., and Vierstra, R. D. (2005). A lightsensing knot revealed by the structure of the chromophore-binding domain of phytochrome. Nature 438, 325-331. doi: 10.1038/nature04118

Walker, A. R., Lee, E., Bogs, J., McDavid, D. A. J., Thomas, M. R., and Robinson, S. P. (2007). White grapes arose through the mutation of two similar and adjacent regulatory genes. Plant J. 49, 772-785. doi: 10.1111/j.1365-313X.2006.02997.x

Wang, C., Chen, C., and Wang, S. (2009b). Changes of flavonoid content and antioxidant capacity in blueberries after illumination with UV-C. Food Chem. 117, 426-431. doi: 10.1016/j.foodchem.2009.04.037

Wang, S. Y., Chen, C. T., and Wang, C. Y. (2009a). The influence of light and maturity on fruit quality and flavonoid content of red raspberries. Food Chem. 112, 676-684. doi: 10.1016/j.foodchem.2008.06.032

Wang, Y., Zhou, B., Sun, M., Li, Y., and Kawabata, S. (2012). UV-A light induces anthocyanin biosynthesis in a manner distinct from synergistic blue + UVB Light and UV-A/blue light responses in different parts of the hypocotyls in turnip seedlings. Plant Cell Physiol. 53, 1470-1480. doi: 10.1093/pcp/ pcs088

Wei, Y. Z., Hu, F. C., Hu, G. B., Li, X. J., Huang, X. M., and Wang, H. C. (2011). Differential expression of anthocyanin biosynthetic genes in relation to anthocyanin accumulation in the pericarp of Litchi chinensis Sonn. PLoS ONE 6:e19455. doi: 10.1371/journal.pone.0019455

Wheeler, S., Loveys, B., Ford, C., and Davies, C. (2009). The relationship between the expression of abscisic acid biosynthesis genes, accumulation of abscisic acid and the promotion of Vitis vinifera L. berry ripening by abscisic acid. Aust. J. Grape Wine Res. 15, 195-204. doi: 10.1111/j.1755-0238.2008.00045.x

Wu, J., Zhao, G., Yang, Y. N., Le, W. Q., Khan, M. A., Zhang, S. L., et al. (2013). Identification of differentially expressed genes related to coloration in red/green mutant pear (Pyrus communis L.). Tree Genet. Genomes 9, 75-83. doi: 10.1007/s11295-012-0534-3

Xu, F., Cao, S., Shi, L., Chen, W., Su, X., and Yang, Z. (2014). Blue light irradiation affects anthocyanin content and enzyme activities involved in postharvest strawberry fruit. J. Agric. Food Chem. 62, 4778-4783. doi: 10.1021/jf501120u

Yang, B., Zheng, J., Laaksonen, O., Tahvonen, R., and Kallio, H. (2013). Effects of latitude and weather conditions on phenolic compounds in currant (Ribes spp.) cultivars. J. Agric. Food Chem. 61, 3517-3532. doi: 10.1021/jf4000456

Zhang, X., Allan, A. C., Yi, Q., Chen, L., Li, K., and Shu, Q. (2011). Differential gene expression analysis of Yunnan red pear, Pyrus pyrifolia, during fruit skin coloration. Plant Mol. Biol. Rep. 29, 305-314. doi: 10.1007/s11105-010-0231-Z

Zhang, Z. Z., Che, X. N., Pan, Q. H., Li, X. X., and Duan, C. Q. (2013). Transcriptional activation of flavan-3-ols biosynthesis in grape berries by UV irradiation depending on developmental stage. Plant Sci. 208, 64-74. doi: 10.1016/j.plantsci.2013.03.013

Zheng, J., Yang, B., Ruusunen, V., Laaksonen, O., Tahvonen, R., Hellsten, J., et al. (2012). Compositional differences of phenolic compounds between black currant (Ribes nigrum L.) cultivars and their response to latitude and weather conditions. J. Agric. Food Chem. 60, 6581-6593. doi: 10.1021/jf30 12739

Zheng, Y., Li, J. H., Xin, H. P., Wang, N., Guan, L., Wu, B. H., et al. (2013). Anthocyanin profile and gene expression in berry skin of two red Vitis vinifera 
grape cultivars that are sunlight dependent versus sunlight independent. Aust. J. Grape Wine Res. 19, 238-248. doi: 10.1111/ajgw.12023

Zhou, B., Li, Y., Xu, Z., Yan, H., Homma, S., and Kawabata, S. (2007). Ultraviolet A-specific induction of anthocyanin biosynthesis in the swollen hypocotyls of turnip (Brassica rapa). J. Exp. Bot. 58, 1771-1781. doi: 10.1093/jxb/erm036

Zhou, Y., Guo, D., Li, J., Cheng, J., Zhou, H., Gu, C., et al. (2013). Coordinated regulation of anthocyanin biosynthesis through photorespiration and temperature in peach (Prunus persica f. atropurpurea). Tree Genet. Genomes 9, 265-278. doi: 10.1007/s11295-012-0552-1

Zhou, Y., and Singh, B. R. (2004). Effect of light on anthocyanin levels in submerged, harvested cranberry fruit. J. Biomed. Biotechnol. 5, 259-263. doi: 10.1155/S1110724304403027

Zifkin, M., Jin, A., Ozga, J. A., Zaharia, L. I., Schernthaner, J. P., Gesell, A., et al. (2012). Gene expression and metabolite profiling of developing highbush blueberry fruit indicates transcriptional regulation of flavonoid metabolism and activation of abscisic acid metabolism. Plant Physiol. 158, 200-224. doi: 10.1104/pp.111.180950
Conflict of Interest Statement: The authors declare that the research was conducted in the absence of any commercial or financial relationships that could be construed as a potential conflict of interest.

Received: 05 July 2014; paper pending published: 31 July 2014; accepted: 19 September 2014; published online: 09 October 2014.

Citation: Zoratti L, Karppinen K, Luengo Escobar A, Häggman H and Jaakola L (2014) Light-controlled flavonoid biosynthesis in fruits. Front. Plant Sci. 5:534. doi: 10.3389/fpls.2014.00534

This article was submitted to Plant Metabolism and Chemodiversity, a section of the journal Frontiers in Plant Science.

Copyright (c) 2014 Zoratti, Karppinen, Luengo Escobar, Häggman and Jaakola. This is an open-access article distributed under the terms of the Creative Commons Attribution License (CC BY). The use, distribution or reproduction in other forums is permitted, provided the original author(s) or licensor are credited and that the original publication in this journal is cited, in accordance with accepted academic practice. No use, distribution or reproduction is permitted which does not comply with these terms. 